\title{
Securitization without Adverse Selection: The Case of CLOs
}

\section{Citation}

Benmelech, Effi, Jennifer Dlugosz, and Victoria Ivashina. "Securitization without Adverse

Selection: The Case of CLOs." Journal of Financial Economics 106, no. 1 (October 2012): 91-113.

\section{Published Version}

http://dx.doi.org/10.1016/j.jineco.2012.05.006

\section{Permanent link}

http://nrs.harvard.edu/urn-3:HUL.InstRepos:11337409

\section{Terms of Use}

This article was downloaded from Harvard University's DASH repository, and is made available under the terms and conditions applicable to Open Access Policy Articles, as set forth at http:// nrs.harvard.edu/urn-3:HUL.InstRepos:dash.current.terms-of-use\#OAP

\section{Share Your Story}

The Harvard community has made this article openly available.

Please share how this access benefits you. Submit a story.

\section{Accessibility}




\title{
Securitization without Adverse Selection: The Case of CLOs
}

\author{
Efraim Benmelech ${ }^{1}$ \\ Harvard University and NBER \\ Jennifer Dlugosz ${ }^{2}$ \\ Federal Reserve Board \\ Victoria Ivashina ${ }^{3}$ \\ Harvard University and NBER
}

In this paper, we investigate whether securitization was associated with risky lending in the corporate loan market by examining the performance of individual loans held by CLOs. We employ two different datasets that identify loan holdings for a large set of CLOs and find that adverse selection problems in corporate loan securitizations are less severe than commonly believed. Using a battery of performance tests, we find that loans securitized before 2005 performed no worse than comparable unsecuritized loans originated by the same bank. Even loans originated by the bank that acts as the CLO underwriter do not show underperformance relative to the rest of the CLO portfolio. While there is some evidence of underperformance for securitized loans originated between 2005 and 2007, it is not consistent across samples, performance measures, and horizons. Overall, we argue that the securitization of corporate loans is fundamentally different from securitization of other assets classes because securitized loans are fractions of syndicated loans. Therefore, mechanisms used to align incentives in a lending syndicate are likely to reduce adverse selection in the choice of CLO collateral.

JEL classification: G21, G23, G24

Keywords: Structured finance; Collateralized loan obligations (CLOs); CDOs; Syndicated loans

\footnotetext{
${ }^{1}$ Harvard University, Littauer Center, Cambridge, MA 02138. E-mail: effi_benmelech@ harvard.edu.

${ }^{2}$ Federal Reserve Board, $20^{\text {th }} \&$ C St. NW, Washington, DC 20551. E-mail: jennifer.l.dlugosz@ frb.gov

${ }^{3}$ Harvard Business School, Baker Library 233, Boston, MA 02163. E-mail: vivashina@ @bs.edu.

We thank Darrell Duffie, Paul Gompers, Jeremy Stein, Greg Nini, Gary Gorton, Charlotte Ostergaard, Amit Seru, James Vickery, Paul Willen, seminar participants at, the Federal Reserve Board, the Federal Reserve Bank of New York, Harvard University, UNC, London School of Economics, Wharton, University of Florida, Berkeley, NERA, the World Bank, the Brattle Group, and participants at the American Finance Association annual meeting, the Yale Conference on Financial Crisis, and Financial Intermediation Society Annual Meeting, and especially an anonymous referee and the editor (Bill Schwert) for helpful comments. Jessica Dias and Kate Waldock provided excellent research assistance. We acknowledge research support from the Division of Research at Harvard Business School. Benmelech is grateful for financial support from the National Science Foundation under CAREER award SES0847392. We are especially grateful to LSTA and Markit for assisting us with secondary market loan prices and CDS data.
} 


\section{Introduction}

In the third quarter of 2007 , structured finance markets ground to a halt after nearly a decade of phenomenal growth. Mortgage-backed securities (MBSs) and Collateralized Debt Obligations (CDOs) suffered a major blow to their reputation after being tied to a recordbreaking wave of downgrades and bank losses. Both academics and practitioners have blamed securitization for encouraging risky lending and for being responsible, in part, for the recent credit crisis. In particular, several empirical studies of MBSs [Keys, Mukherjee, Seru, and Vig (2010); Seru and Vig (2010); Drucker and Mayer (2008); Nadauld and Sherlund (2009)] have shown that securitization resulted in lower lending standards, which led to adverse selection in the collateral pools underlying these products.

In this paper, we focus on collateralized loan obligations (CLOs) which are CDOs backed by corporate loans. We analyze the performance of loans purchased by CLOs between 1997 and 2007 using a battery of performance tests. ${ }^{1}$ Contrary to the findings in studies of other forms of securitization, we find no consistent evidence that securitized corporate loans were riskier than similar loans that were not securitized. When looking separately at the early (1997-2004) and late (2005-2007) periods of securitization, we find mixed evidence concerning the underperformance of securitized loans originated during the latter period. This result is sensitive to the choice of the sample, the horizon over which we measure performance, and the performance measure we use. Thus, even for the later period of securitization there is no consistent evidence that adverse selection played an important role in securitized lending. Further, when we examine a subset of securitized loans for which we expect agency problems to be particularly pronounced-loans purchased by the CLO from its underwriter — we also find no

\footnotetext{
${ }^{1}$ Throughout the paper we refer to loans with CLO lenders in the syndicate as securitized loans or loans purchased by CLOs.
} 
evidence of underperformance regardless of the time horizon, sample, or performance measures used.

While the overall result can be viewed as a negative finding — we find that securitization is not statistically significant in predicting poor performance-there are important positive results in our paper: Adverse selection is not an inevitable consequence of securitization, and not all securitized markets are the same. The fact that the only evidence on the underperformance of securitized loans is weak and concentrated in the second year of among loans originated in the 2005-2007 period could be due to the passive nature of CLOs and overheated market conditions driven by large CLO issuance and institutional investors' demand for corporate loans more broadly (Ivashina and Sun, 2011a). ${ }^{2}$ Recent findings by Bord and Santos (2011) indicate, that overheated market conditions over this period were also connected to the reduction in the share of the loan ("skin in the game") retained by the originating bank. ${ }^{3}$

A potential explanation for the different findings between our paper and those that study mortgage securitization has to do with the fact that corporate loans are only partially securitized. Corporate loans are significantly larger than mortgages and are typically syndicated; that is, at origination, the loans are funded by a group of banks and institutional investors. Fractions of the same underlying loan are simultaneously held by multiple CLOs as well as by other institutional investors and banks. In addition, the bank that originated the loan (the lead bank) typically retains a fraction of the loan on its balance sheet and each underlying loan is rated. In contrast, subprime mortgages are typically sold in one piece to MBS issuers with little to no risk retention

\footnotetext{
${ }^{2}$ Consistent with this interpretation, following the 2007-2009 economic crisis, low borrowing costs and loose credit standards have returned ahead of the securitization market's recovery. See "Cov-Lite Loans Make a Return", Wall Street Journal, March 26, 2010; "Risky loans stage comeback”, Financial Times, March 13, 2011.

${ }^{3}$ The time pattern of shrinkage in "skin in the game" is clearly shown in Ivashina and Scharfstein (2010).
} 
by the originator. Large corporate loans, therefore, involve a greater number of formal and informal screeners whose reputation is at stake and the loan originator has "skin in the game".

We argue that the size of the loan and the syndication process make corporate loans less prone to adverse selection when securitized. Our view is consistent with a large body of research studying the mechanisms that mitigate asymmetric information in market for corporate loans [Gorton and Pennacchi (1995); Dennis and Mullineaux (2000); Sufi (2007); Drucker and Puri (2009); Ivashina (2009)]. These studies find that the lead bank's share and the lead's reputation are the key mechanisms for reducing information asymmetry between the originating bank and other lenders in loan syndication. Therefore, syndication before securitization reduces the potential for adverse selection. Moreover, in contrast to residential mortgages corporate loans are large. The average securitized corporate loan is roughly $\$ 522$ million (and the minimum syndicate participation amount is $\$ 1-\$ 5$ million) compared to an average loan size of only $\$ 150$ $\$ 190$ thousand for residential mortgages. We argue that if there are fixed costs of monitoring a borrower, investors are more likely to monitor larger loans or assets which make their collateral pools less susceptible to adverse selection.

Is it trivial then that securitization of syndicated corporate loans is adverse-selection proof? Judging by the sudden contraction in CLO issuance (along with other structured issuance) in the third quarter of 2007 and the absence of a subsequent rebound, the answer is no (see Fig. 1 and Fig. 2). A simultaneous disconnect between yields on existing CLO tranches and corporate bonds with similar ratings suggests that the market perceived the underlying problem as specific to structured finance. Indeed, the disappearance of CLO issuance coincided with the widespread 
fear that strong demand for securitizable assets may have led to risky lending in the corporate sector. $^{4}$

To the best of our knowledge, this is the first paper to provide a comprehensive analysis of the performance of securitized corporate loans and to suggest that adverse selection is not an inevitable consequence of securitization. Our results are consistent with Shivdasani and Wang (2009) who find that an increase in securitization did not lead to riskier LBOs. The contribution of our study is that we directly observe CLO ownership of a large sample of loans originated from 1997 to 2007, which allows us to look at a broader set of corporate transactions and to investigate the effect of securitization on the loan market more generally. In a recent paper, Bord and Santos (2011) use data from Shared National Credit (SNC) Program to look at securitized loan delinquency. ${ }^{5}$ Similarly to our findings, they show that underperformance results are concentrated in the late period of securitization and over a long-term horizon. However, Bord and Santos (2011) rely on only one discrete measure of performance reported by the banks at an annual level. Other papers that look at the securitization of corporate loans include Ivashina and Sun (2011a) and Nadauld and Weisbach (2011). Both papers look at pricing of loans purchased by CLOs; neither paper examines the performance of securitized loans. We use loan spread as a

\footnotetext{
${ }^{4}$ See for example "Seeds of Credit Crunch Grow in LBO Loan Market," Reuters, 19 June 2007: In the old days of relationship banking, banks relied on credit quality control and huge balance sheets to ride out any problems, but CLO investors may be more short-term oriented. Lack of credit quality control by some managers of CLOs is particularly frightening to veteran private equity investors. "What all of this will show - and it will show more as CLOs become more popular - is that risk management has not been very well practiced," said billionaire financier Wilbur Ross, founder of private equity firm WL Ross \& Co. Also, "Easy Money: Behind the Buyout Surge, a Debt Market Booms -- CLOs Spark Worries of Volatility and Risk; Loan Standards Loosen,” WSJ, 26 June 2007: Investors searching for higher yields have put so much money into CLOs that even weak companies can get loans at relatively low interest rates... These days, banks that arrange large buyout financings hold on to very little of the loans themselves. Bank underwriting standards have slipped as banks have become mere intermediaries.

${ }^{5}$ Although Board and Santos use a different way of identifying securitized loans from the two ways we use in this paper, our sample and their sample are very similar in size. Our sample of securitized loans constructed from a proprietary data on CLO loan portfolios and covering 2005-2007 period has roughly 420 loans (plus minus a few observations depending on the performance measure). Bord and Santos matched sample covering 2004-2008 has 596 securitized loan-facilities (without merging SNC data to Compustat or DealScan.)
} 
control variable in our analysis, thus differences in performance cannot be explained by differences in loan spreads.

The differences between mortgage and corporate loan securitizations in terms of the securitization process and the subsequent collateral performance have broad implications for the design of securitized assets and provide suggestive evidence in support of the spirit of the recent financial legislation. In an effort to reduce agency problems in securitization going forward, Section 941 of the Dodd-Frank Wall Street Reform and Consumer Protection Act requires federal agencies to develop credit risk retention requirements for securitizers and originators. Our paper is consistent with the effectiveness of risk retention mechanisms as we study a sector of the structured finance market where risk retention by originators existed prior to the new legislation.

It is worth noting that many CLOs were downgraded or placed on negative credit watch during the crisis. While CLO downgrades were partly triggered by deterioration in the credit quality of corporate borrowers during this time, aggressive adjustments to rating agency methodologies also played a role. Despite widespread downgrades, there were very few defaults on CLO tranches. According to the LSTA, less than 1\% of CLOs rated by Moody's defaulted. We should stress that our findings do not imply that securitized loans should perform well in absolute terms, but rather that securitized loans should not perform worse than other noninvestment grade loans syndicated to non-banks. This leaves open the possibility that all leveraged loans are of an intrinsically worse quality than believed at the time of loan origination. Also, by design, CLOs primarily acquire non-investment grade securities so the pool of securitized loans should be expected to underperform the overall population of loans. 
The rest of the paper is organized in four sections. Section 2 highlights the key informational frictions involved in the securitization of corporate loans. Section 3 describes the data including how we identify securitized loans and measure performance. Section 4 presents the empirical results, and section 5 concludes.

\section{Collateralized loan obligations and adverse selection}

Our results are organized around two hypotheses related to the central channels that could lead to adverse selection in the quality of CLO collateral:

H1 (extensive margin): Loans syndicated to CLOs (securitized loans) are worse quality than other syndicated loans (unsecuritized loans).

H2 (intensive margin): Securitized loans arranged by the bank underwriting the CLO are worse quality than other securitized loans within the same portfolio. (Notice that the second hypothesis - the intensive margin — is conditional on securitization.)

Since adverse selection in CLO collateral may be only observable ex-post, we focus on ex-post performance controlling for loan characteristics at origination,

\subsection{CLOs and the effects of securitization (H1)}

The key friction underlying the securitization process is asymmetric information about loan quality. Fig. 3 illustrates the different steps in the securitization process and the agents involved. To structure a CLO, a collateral manager-typically an investment management 
company—sets up a bankruptcy-remote special purpose vehicle (SPV) ${ }^{6}$ The collateral manager then assembles a collateral portfolio by acquiring pieces of syndicated corporate loans, engages with the underwriter and credit rating agency to structure and rate the deal, and issues securities to investors backed by the principal and interest payments from the loans. (These CLOs, also known as "cash-flow" or "cash" CLOs, are the focus of our paper.) To put together a collateral pool a CLO usually participates in over a hundred different syndications. The average CLO size is $\$ 500$ million and the average size of an individual loan holding in a CLO portfolio is $\$ 2$ to $\$ 3$ million. (While the average size of a high yield syndicated loan is $\$ 522$ million, each participant in the syndicate finances only a fraction of the loan, hence the small size of individual loan holdings in a CLO portfolio). Because multiple agents are involved, there is an information cascade between the originating banks, the CLO manager, and the ultimate investors in the $\mathrm{CLO}^{7}$, where the originating bank is best informed and ultimate investors in the CLO are worst informed about loan quality. CLOs differ from other institutions that participate in the high yield loan market in several ways which could result in CLO managers having weaker incentives to screen and monitor than other market participants. First, CLO managers' compensation is only weakly tied to deal performance. CLO managers receive a base fee on the order of 40-50 basis points per year, typically senior to all notes (Tavakoli, 2002). CLO managers are not required to hold equity in the deal, but there are cases where they own a share of the equity, receive an

\footnotetext{
${ }^{6} \mathrm{~A}$ bank can structure a CLO backed by originated loans to reduce its risk exposure. However, the Securities Industry and Financial Markets Association (SIFMA) reports that in 2007, 97\% of corporate loans CLOs were structured by financial institutions that did not originate loans and instead acquired pieces of loans at syndication or in the secondary market with the purpose of securitization. This type of CLO-in which the issuer did not originate the loans-is referred to as an "arbitrage CLO."

${ }^{7}$ When talking about lenders or investors in loans, we use the term "CLO investor" to refer to special purpose vehicles (SPVs) that directly invest in syndicated loans. "Ultimate investors in CLOs" refers to individuals, funds, or companies that purchase the securities issued by the CLO (e.g., insurance companies that bought AAA-rated CLO tranches). The difference between these two entities is illustrated in Figure 3. We classify loan as securitized if it was acquired by an SPV. In the data, we do not observe the ultimate investors in CLOs.
} 
incentive fee that is subordinate to equity, or have a partial claim on the residual interest. ${ }^{8}$ Judging from a random sample of CLO rating reports, we estimate that CLO managers have equity-like incentives in approximately $50 \%$ of deals. However, a back of the envelope calculation suggests that, even in these cases, base management fees are an order of magnitude larger than incentive fees and, therefore, that CLO management is primarily a volume business. ${ }^{9}$

A second distinctive feature of CLOs (compared to banks and other investors in syndicated loans) is that their cost of funding is largely determined by rating agency models. The models used by the credit rating agencies to evaluate CLO portfolios and rate deals rely primarily on loan ratings to assess the default risk of the underlying collateral. As a result, CLO managers might select worse quality loans because they exert relatively less effort on collateral selection. ${ }^{10}$ (Within a given rating class, the CLO manager also has some incentive to select loans with a higher spread, however we control for spread throughout the paper.)

Meanwhile, there are some constraints that should restrict a CLO manager's risk taking. In particular, downgrades of the collateral can force the manager to pay down notes early, thus forgoing an annual fee. Therefore, a CLO manager cares about deterioration in credit ratings of the assets in his portfolio because too many downgrades could lead to deal termination. The manager also faces a reputational constraint. When assets in the collateral pool miss payments or

\footnotetext{
${ }^{8}$ An example of an incentive management fee taken from Benmelech and Dlugosz's (2009) sample is "The manager receives an incentive fee after equity has achieved and IRR of 14\%". An example of a manager having a claim on residual interest without having made an equity investment is "Once equity holders have achieved a 14\% IRR, residual interest proceeds are split 80/20 between equity holders and the manager."

${ }^{9}$ Suppose a CLO manager earns a base fee of 50 basis points per year and has a claim to $20 \%$ of residual interest after equity achieves an IRR of 14\%. According to Fabozzi, Goodman and Lucas (2006, p. 370), $18 \%$ is an optimistic estimate of the return on CLO equity. Given an average CLO size of $\$ 500$ million and an average equity tranche worth $10 \%$ of deal par, the annual base fee would be $\$ 2.5$ million $(0.005 * 500)$ while the annual incentive fee would be $\$ 0.4$ million $(0.2 *(.18-.14)(0.10 * 500))$.

${ }^{10}$ At least one rating agency model primarily used rating, maturity, seniority, jurisdiction, and industry to compute an expected loss distribution for the underlying collateral. Benmelech and Dlugosz (2009) and Coval, Jurek, and Stafford (2009) provide extensive detail on rating models. Also see the testimony of Eric Baggesen, Senior Investment Officer California Public Employees' Retirement System before the House Committee on Oversight and Government Reform on September 30, 2009.
} 
default, the deal's equity holders bear the first loss. If equity holders do not earn an adequate return, the manager may have difficulty selling the equity tranche in future deals. Both of these constraints should attenuate agency problems between CLO managers and ultimate CLO investors in the selection of the collateral. However, these mechanisms are not unique to corporate loan securitizations and given the evidence on mortgage securitization, their effectiveness is questionable.

While CLOs have weaker incentives to screen and monitor than more traditional participants in the corporate loan market, the fact that the underlying loans in CLOs are syndicated might counteract the potential negative effects on loan quality. Syndication before securitization is a key difference between corporate loan securitization and mortgage securitization. ${ }^{11}$ After origination, a subprime mortgage ( $\$ 150-\$ 190$ thousand on average) is typically sold by the originating lender as part of a pool to other investors. In the case of a securitization, this mortgage pool would be used as part of the collateral held by SPV. At no point is any of the individual mortgages split into parts; i.e., there is only one direct claim against the borrower who took the original mortgage.

On the other hand, the loans held by CLOs are syndicated, that is, at origination each loan (\$522 million on average) is funded by a group of lenders. ${ }^{12}$ Every syndicate participant, including CLOs, holds a direct pro-rata claim against the borrower. Syndicated loans generally involve certain mechanisms that ameliorate asymmetric information between the lead bank and

\footnotetext{
${ }^{11}$ Here we are referring to the securitization process for non-conforming mortgages (jumbo, alt-A, and subprime) that do not meet criteria for securitization by GSEs.

${ }^{12}$ When a company takes out a high-yield syndicated loan the loan package would typically consist of multiple pieces also known as facilities, for example: (i) roughly $10 \%$ of the package is a revolving line, (ii) another 25-30\% is a term loan " $\mathrm{A}$ ", (iii) $50 \%$ is split across first lien institutional facilities (primarily term loan "B"); (iv) the rest is a subordinate term loan facility senior to any outstanding bonds. Although all facilities are covered by the same loan contract, they are typically held by a different investor base. Revolving lines are almost exclusively held by banks. Term loan "A" is also syndicated to banks and other tranches - term loan " $\mathrm{B}$ " as well as subordinated tranchesbeing syndicated to institutional investors including CLOs. I.e., a CLO typically holds a fraction of a Term loan B.
} 
participants. These mechanisms include the lead's reputational concerns and the implicit requirement that the lead bank retain a share of the loan on its balance sheet. Prior research has shown that lead banks on average retain $27 \%$ of a loan. To the extent that these mechanisms continued to function effectively, we might not see a decline in lending standards associated with CLOs. However, it is possible that lead banks' incentives to conduct due diligence and monitor borrowers have become weaker due to broader syndication resulting from large CLO demand. For example, Ivashina and Scharfstein (2010) show the average share of loans retained by lead banks fell dramatically during the 2004-2007 credit expansion.

Syndication also implies that even when a loan is securitized (i.e., has CLOs in the syndicate) there may be other non-CLO lenders in the syndicate as well. If other lenders are able to compensate for weak screening and monitoring by CLOs, we might not observe a drop in loan quality associated with securitization. However, CLOs tend to cluster on loans and other lenders might have additional motives for investing in particular loans. In particular, other lenders might internalize the cost of adverse selection for a given loan because participating in the syndicated loan market could lead to other sources of revenue. For example, “...the spread offered to pro rata investors (banks) is important, but even more important, in most cases, is the amount of other, fee-driven business a bank can capture by taking a piece of a loan" (Standard and Poor's, 2006.) The same argument is likely to be true for insurance companies. On the other hand, hedge funds and mutual funds could be willing to accept higher risk because they could use information obtained in the loan market to trade in other securities (Ivashina and Sun, 2011b). In general, the syndicated loan market is a private market and access to deal flow might be another reason why investors would be willing to pay an additional cost on some loans. Ultimately, whether securitization led to risky lending in the corporate loan market is an empirical question. 


\subsection{Effects of underwriting in securitization (H2)}

In addition to the collateral manager, a CLO has an underwriter (typically a bank) responsible for screening the loan portfolio and working with the rating agencies to get CLO tranches rated, priced, and allocated. In essence, the role of an underwriter in CLO deals is similar to the role of an underwriter in stock or bond issuance. As compensation, the underwriter receives a fee on the notional value of the deal. While the collateral manager has formal authority over asset selection, the underwriter may exert influence over collateral choice. Although the presence of an underwriter should improve the screening of the underlying collateral, underwriting banks may use this channel to sell fractions of their own riskier loans to CLOs. Put differently, even if CLOs do not end up with worse quality loans than other loan investors on average, they may end up with worse quality loans when they buy them from the underwriter of their deal. We estimate that about $10 \%$ of loans sold to CLOs were originated by the CLO underwriter.

\section{Data}

\subsection{Securitized loans sample construction}

To test the first hypothesis we employ two different samples that identify loans held by CLOs. The first sample - which we refer to as the "at-origination sample"-includes loans originated between 1997 and May 2007. In this sample, we determine whether a loan was securitized by checking for the presence of CLOs in the lending syndicate at the time of origination and at the time of the first loan amendment. 
The second sample — which we refer to as the "portfolio sample"—is constructed using a proprietary source that enables us to observe the complete portfolios of a comprehensive set of CLOs. These data consist of monthly CLO trustee reports covering the period between July 2008 and January 2010. Loans that appear in the CLOs' portfolios are labeled as securitized. Below, we describe the two samples in more detail and discuss potential selection issues.

\subsubsection{The first sample: "At-origination sample"}

To identify loans that were purchased by CLOs at origination we start with the sample of loans to U.S. companies (public and private) reported in Reuters' DealScan containing Term loan $\mathrm{B}$ or $\mathrm{C}$ facilities. We also include all term loans with a credit rating that have non-bank institutions, such as hedge funds, mutual funds, pension funds, distressed funds, or structured financial vehicles, in the lending syndicate.

Generally speaking, there are two distinct investor groups in the loan market: banks (the traditional investors) and institutional investors. Institutional investors, including CLOs, primarily participate in the non-investment grade (leveraged) segment of the loan market and compete for the same loans. Term loans B and C are specifically structured for non-bank, institutional investors. The term loan B or C label refers to a facility within a loan package. Data used in the analysis is collapsed to one observation (one facility) per loan. That is, we use the Term Loan B facility where it exists. In cases where institutional investors are part of the syndicate but there is no Term Loan B facility, we use Term Loan C or Term Loan facilities, in that order.

We follow two steps to identify CLO ownership of loans. First, we search the list of lenders at the time of syndication available through DealScan. As a second step, we search the 
list of lenders at the time of the first loan amendment. ${ }^{13}$ The identity of the lenders (names of SPVs) is crosschecked with a list of CLOs constructed by combining information from: (i) Reuters CDO pipeline, (ii) Standard\&Poor's (S\&P) Quarterly CDO Deal List, and (iii) S\&P's RatingsDirect.

We supplement the primary market information from DealScan with data from loan amendments to fully capture all securitized loans. Information available at the time of origination might under-report CLO ownership of loans in the presence of warehousing (when banks or other institutions temporarily hold loans with the intent of selling them to CLOs). Not being able to observe CLO ownership perfectly might lead us to misclassify securitized loans as unsecuritized, biasing the results against finding differences in performance between the two groups.

We mitigate this concern by detecting warehousing through loan amendments. Material loan amendments-changes affecting the spread, maturity, or loan amount-require the unanimous approval of all lenders. In such cases, the signatures and identities of all the lenders appear at the bottom of the document. We collect the first material amendment for each loan in our sample and search the signers for CLOs. Loan amendments are available to us from 1997 through 2007; accordingly, we constrain the overall loan sample to this period.

We classify loans as securitized if there is at least one CLO in the lending syndicate at the time of loan origination or at the first loan amendment. The final sample contains 487 loans, 302 of which we classify as securitized or having CLO investors. 185 loans did not have any CLOs in the syndicate at origination or at the time of amendment so we classify them as unsecuritized;

\footnotetext{
${ }^{13}$ Amendments and the signing lenders are typically disclosed as a part of 10-Q and 10-K SEC filings (see Ivashina and Sun, 2011b). The focus on the first loan amendment is to assure that it is close to loan origination date, i.e., we are capturing loans that were intended to be securitized at origination.
} 
these loans constitute our control group. The set of unsecuritized loans is conditional on having a material loan amendment, which explains the relatively small sample size. We ran all of the reported tests confining the at-origination sample to the 292 loans (out of 302) that had CLOs in the syndicate in Dealscan. Perhaps not surprisingly, the results are practically identical and do not affect the conclusions.

For 104 of the 302 securitized loans (34\%), we detected additional CLOs in the syndicate through amendments in addition to those picked up by DealScan. However, of these 302 securitized loans, $292(97 \%)$ had at least one CLO in the syndicate at origination according to DealScan. In other words, most loans that appear in CLOs at the time of amendment also had at least one CLO in the syndicate at origination, which should diminish concerns about underidentifying securitization because of warehousing.

We consider several potential sources of selection bias. Tests of the first hypothesis are based on a comparison of securitized (treatment group) and unsecuritized (control group) loans. To ensure that loans in the control group were not intended for sale to a CLO at origination, our control group was constrained to loans with amendments. ${ }^{14}$ Yet, our treatment group includes loans with and without loan amendments, as long as they had a CLO in the syndicate at origination. If amended and un-amended loans are fundamentally different then our results could be biased. However, it is unclear whether the presence of an amendment reflects positive or negative news. If observable amendments are a reflection of successful renegotiations and loans without amendments in fact reflect failed renegotiations, then our control group is on average of better quality. Alternatively, if most of the firms soliciting amendments and receiving

\footnotetext{
${ }^{14}$ This is a conservative criterion because all but ten loans that had CLOs in the syndicate at the time of amendment also had CLOs in the syndicate at origination; that is, the presence of a CLO in the syndicate at origination appears to be a reliable proxy of whether the loan is securitized.
} 
amendments are troubled firms, then our treatment group is on average of better quality. We address this issue empirically by re-examining the results in the subsample where treatment and control group were constrained to the sample with loan amendments; the results do not change our conclusions.

Overall, we identify 555 unique CLO investors corresponding to 302 securitized loans. On average, our sample contains 6 loans per CLO. The median size of a CLO issued during that period was $\$ 460$ million (Benmelech and Dlugosz, 2009) and the average minimum investment in the institutional loan market is $\$ 5$ million, hence, as a lower bound, six loans represent roughly $6 \%$ of the collateral pool. ${ }^{15}$ While the at-origination sample provides only a partial look at each CLO's collateral pool, we identify some loans for approximately $60 \%$ of outstanding U.S. CLOs.

\subsubsection{The second sample: "Portfolio sample"}

The second sample used in the analysis comes from Creditflux, a leading global information source for credit trading and investing which maintains a comprehensive database of CDOs and credit hedge funds. We have the entire Creditflux CLO database, which includes monthly trustee reports detailing the complete investment portfolios for a large set of CLOs covering the period between July 2008 and January 2010. We hand match the loan portfolios to DealScan and Compustat. Matching to DealScan returns 2,297 unique U.S. corporate loans. The sample covers 277 U.S. CLOs issued between 1999 and 2008. Using the total CLO volume tracked by the Securities Industry and Financial Markets Association (SIFMA), and assuming that CLOs, on average, have a par value of $\$ 500$ million, we estimate that our sample covers

\footnotetext{
${ }^{15}$ Many CLOs are not $100 \%$ invested or hold other types of securities in addition to corporate loans. Most CLOs are structured as 'revolving pools' that allow the manager to turnover 10 to $20 \%$ of the collateral per year for the first five to seven years of the typical twelve year life of a CLO.
} 
46\% of CLOs issued between 2003 and 2007. (This is a lower-bound estimate of coverage because the SIFMA statistics include synthetic CLOs.) On the other hand, comparing this sample to the one in Benmelech and Dlugosz (2009) indicates that the new sample covers $65 \%$ of deals issued between 2003 and 2007. (This is likely to be an upper-bound because Benmelech and Dlugosz (2009) only look at S\&P rated vehicles.)

In this sample, any loan that appears in a CLO's portfolio is categorized as securitized. As before, a sample of unsecuritized loans is drawn from the set of loans in Dealscan that have Term Loan B or C facilities or are held by other institutional investors more broadly. We limit the treatment and control groups to loans originated between January 2005 and July 2007 that mature between 2010 and 2015 for two reasons. First, our CLO portfolio observations span the period from 2008 to 2010. We could misclassify earlier loans as unsecuritized if they matured before our CLO portfolio observations start. Second, the focus of our study is the performance of loans that were originated with the intent of being sold to CLOs. Securitization (CLOs' purchases of loans) in the corporate loan market is a continuous process as opposed to a one-shot deal as in the MBS market. CLOs are allowed to turnover a limited portion of their collateral for the first few years of their life and loans trade on the secondary market. As a result, loans that were not owned by CLOs at origination might end up in a CLO portfolio later on. This is especially true for the period of 2008 and beyond. Over this period, very few new loans were originated and many companies went bankrupt, expanding CLOs' penetration of the loan market. Thus, the potential challenge in the portfolio sample is the opposite of the one we face in the atorigination sample; we are concerned that we could misclassify loans as securitized (type II error). Limiting the treatment and control groups to loans originated between January 2006 and July 2007 renders similar results. 
We should also consider the reverse, that is, the possibility that a loan that was held by CLOs at origination could later be sold. Using data from our "portfolio sample", we find that CLOs tend to hold loans for long periods of time. If a CLO holds a loan in a given month, the probability of this loan still being part of the CLO portfolio in the next month-condition on the loan still outstanding - is $96 \%$ (93\% three month later and $89 \%$ six month later). This is consistent with Benmelech and Dlugosz (2009) who study CLO rating reports and find that the average CLO permits only limited trading during the first third to half of the deal maturity. Thus, only a small fraction of the CLO portfolio is sold and therefore is unlikely to introduce type I error where we misclassify loans as securitized.

\section{Results}

\subsection{Measuring performance}

Both of our hypotheses are motivated by the asymmetry of information between different parties involved in the securitization process. Since we cannot directly observe the more informed party's true opinion of a given loan ex-ante, we proxy for it by examining ex-post performance, controlling for observables at the time of loan origination. For example, if loans sold to CLOs are unobservably worse quality than other syndicated loans, they should perform worse controlling for loan and borrower characteristics at origination.

We use a battery of loan and borrower performance measures for our analysis. These measures are: (i) secondary market loan prices, (ii) loan-level credit rating changes, (iii) changes in the borrower's market-assessed probability of default as measured by changes in credit default swap (CDS) spreads, (iv) borrower credit quality measured by implied default probability from a reduced form version of Merton's (1974) distance-to-default model, and (v) violations of loan 
covenants. As mentioned earlier, we use only one facility per loan because loans are securitized at the facility level. Loan-market prices are facility-level. Credit ratings correspond to the senior (first-lien) facilities within a loan package including the facility that we consider for the analysis. CDS spreads also correspond to senior debt. Covenant violations affect all facilities under the loan package. Implied default probability is a borrower-level measure.

Secondary loan market prices and CDS spreads are dynamically updated, forwardlooking measures of performance. One advantage of these measures is that they are not restricted to publicly traded companies. Many of the loans in our sample are related to a leveraged buyout for which publicly available information ceases to exist after the firms go private. However, loans and CDS contracts continue to trade even if a company is taken private, allowing us to measure performance for private firms as well. Still, secondary market loan prices and CDS spreads are only available for large and liquid names thus restricting the sample to largest borrowers. To overcome this problem we also look at changes in credit ratings, implied default probability, and covenant violations. Credit ratings are not updated continuously and are a discrete measure of performance, thus implied default probability and covenant violations provide a finer measure of performance. While each of these performance measures has its limitations, taken together they provide a comprehensive evaluation of the performance of securitized loans.

\subsubsection{Secondary market loan prices}

Loan-market prices are probably the most direct measure of loan performance. We obtain loan price data from two sources. Data for 2006-2010 is from the Loan Syndications and Trading Association (LSTA) Thomson Reuters LPC Mark-to-Market (MTM) Pricing which contains monthly averages for bid and ask quotes by facility. The data for 1998 through 2004 is from 
Altman, Gande and Saunders (2010). The daily data starts in November 1999, before that we have monthly and weekly quotes. Taken together, we have secondary market loan prices from 1998 to 2010 excluding 2005.

The LSTA reports quotes and not traded prices, but these are the numbers used for MTM purposes. LSTA runs a quarterly study on accuracy by comparing MTM prices to trade prices. According to LSTA MTM prices historically have been a "very accurate" proxy of the transaction prices. ${ }^{16}$ On a daily basis, dealers price what LSTA requests, which is based on the loans held by the lender base. According to LSTA, the pricing service requests pricing on essentially all leveraged syndicated bank loans. As of May 2011, LSTA was pricing 2,600 individual loan facilities from 1,325 U.S. borrowers. Generally the way the process works is that one (or many) customers of the service will add a new loan to their portfolio and then the pricing analysts will research the deal and request pricing from the lead banks that arranged the deal. Multiple dealers price the loans. For a quote to be reported, at least two dealers are required to report information. LSTA reports equally-weighted average quote across all reporting dealers.

Not all the loans are traded and not all traded loans are sufficiently liquid to have quotes. Our results using secondary loan prices are conditional on loans being traded; furthermore they are conditional on loans being traded in the first year following loan origination for at least 6 consecutive months. $40 \%$ of loans in the at-origination sample and $16 \%$ of loans in the portfolio sample meet this requirement and have loan price data. The average first bid in our sample is 99.9 bps (median of 100.3 bps). Gupta, Singh and Zebedee (2008) classify facilities as liquid "if on any day after origination there is a price quote for that loan in our secondary market database,

\footnotetext{
${ }^{16}$ LSTA looks at each loan that traded in a given quarter and compares the transaction and MTM price on trade date. For example, according to the study for the first quarter of 2011 the mean absolute differential between all trade and MTM prices was $49 \mathrm{bps}$, the median $25 \mathrm{bps}$.
} 
and its first quoted bid price is greater than 98 (par loan)"; out of the overall DealScan sample $15 \%$ of facilities meet this criteria. Under this criteria, all loans in our sample are very liquid. This is also confirmed by the fact that a bid-ask spread for loans in our sample is below 1 bps. Overall this is consistent with the fact that secondary loan market liquidity is largely driven by institutional investors as we focus on the loans syndicated to institutional investors (LSTA, 2007.)

To standardize the data over the entire sample, we convert everything to monthly averages. For each of the facilities in our sample, we calculate the percentage change in loan prices in two years after loan origination (two windows, year one and year two). To construct the secondary market price change for a given year we calculate the percentage difference between the average mid-quotes in the first and last month within a year window.(Mid-quotes are an average of bid and ask.) Thus, for a loan originated on January 5, 2005 that starts to trade immediately and trades for the next two years, the first year price change is computed using average mid-quotes corresponding to January 2006 and January 2005. To assure that the price changes are not driven by outliers we control for the annual price volatility computed using monthly averages.

\subsubsection{Credit ratings}

The second measure we examine is downgrades and upgrades of Moody's and S\&P's loan ratings. Loan ratings correspond to senior secured loan facilities and come from GoldSheets. Rating data covers the period between May 2001 and April 2010. We count rating changes if at least one of the rating agencies modified its assessment of the loan. Our rating scale incorporates credit watches so that 'downgrades' include placements onto negative credit watch and 'upgrades' include placements onto positive credit watch. 
Over $99 \%$ of facilities in both the at-origination sample and the portfolio sample are senior secured making these ratings the appropriate measure of performance. ${ }^{17}$ Seniority is assigned at the loan facility level. If several facilities within the same loan package are senior secured debt, these facilities are governed by the same loan contract and they receive the same priority in repayment. The exception to this rule are second-lien (subordinated or mezzanine) facilities, however, these represent a very small faction of the syndicated loans. Moreover, Term loan B's - the focus of our study — are by definition first-lien loans. We should also note that when a syndicated loan is outstanding, seniority is constrained to first-lien facilities within the loan package as no other debt with the same seniority can be outstanding or issued later due to the negative covenants included in a typical loan contract. In that sense, changes in senior secured credit ratings reflect performance of the first-lien facilities and, specifically, the institutional facilities in our sample.

Using credit ratings as a measure of performance potentially introduces a bias against finding underperformance of securitized loans as CLO managers would like to pick borrowers that will have stable ratings. Credit ratings are central inputs to the CLO evaluation models used by the rating agencies and models are typically re-run at regular intervals after issuance to check compliance. In addition, most CLOs include covenants that restrict the manager's asset allocation by credit rating. Violating these covenants or failing a ratings test can trigger accelerated pay-down of the notes or require the manager to adjust the collateral pool through sales and purchases.

\subsubsection{Credit default swaps}

\footnotetext{
${ }^{17}$ Benmelech and Dlugosz (2009) also report that most CLOs are required to hold no less than $90 \%$ of their portfolio in senior secured loans. Given that CLOs typically hold 5-10\% of non-loan collateral in their portfolios, the share of loans in CLOs that is senior secured is even higher.
} 
We obtain CDS data from Markit for the period between 2003 and June 2009. CDS spreads measure the amount an investor would have to pay to insure against a company's default. As a company's default risk rises, its CDS spread increases. We use daily quotes for the CDS corresponding to the 5-year contract on senior unsecured debt. Thus, changes in these CDS spreads reflect changes in the default risk of obligations at the same level of seniority as the institutional facilities in our sample.

For each of the loans in our sample, we calculate the percentage change in CDS in two years after loan origination (two windows, year one and year two). Within a given year window, we use first and last CDS quotes to construct our measure. We also control for the annual volatility computed using daily CDS quotes in the six months prior to the beginning of the performance window.

\subsubsection{Implied probability of default}

Since only a subset of companies in our sample have CDS trading, we also calculate implied default probabilities using the reduced form Merton (1974)-style model described in Bharath and Shumway (2008). Specifically, we look at the change in the borrower's implied 1year default probability following loan origination (two windows, year one and year two). The $t$ 1 implied default probability $\left(\Pi_{t-1}\right)$ is measured as of month-end in the month before loan origination. For example, for a loan originated on January 5, 2005, the $t-1$ implied default probability is measured as of month end of December 2004. The change in the implied default probability over year one is the difference between the values as of month-end December 2005 and month-end December 2004. The year two change is calculated as the difference between month-end December 2006 and month-end December 2005. 
This measure is based on accounting and stock information, so we can only compute it for firms with valid data available in Compustat and CRSP. Furthermore this is the most indirect measure of loan performance as it reflects overall borrower creditworthiness. But unlike credit ratings and covenant violations it is a continuous measure of performance.

\subsubsection{Loan covenant violations}

Data on loan covenant violations is compiled from reading remarks for the loan amendments as reported in DealScan. ${ }^{18}$ Covenant structure is typically set at the loan package level. In other words, a covenant violation would affect every facility under the loan package. Similar to credit ratings and implied default probability, covenant violations are not constrained to firms with traded loans or CDS. Given that covenant violations do not necessary lead to credit rating downgrades they represent a finer measure of performance. However, covenant violations are rare (although not as rare as corporate defaults). Due to the limited number of observations we restrict the analysis to univariate results and report it as a robustness check.

\subsection{Summary statistics}

We begin by reporting descriptive statistics for both samples. As shown in Table 1, Panel A, institutional loans are large loans made to large borrowers; the average loan size is roughly $\$ 600$ million and the average borrower had roughly $\$ 1.7$ billion in sales at the time of loan origination. Generally speaking, loans purchased by CLOs are non-investment grade senior-

\footnotetext{
${ }^{18}$ These remarks records waivers of covenants violations in addition to any changes to the loan contract that might or might not be triggered by a covenant violation. We read through the comments that contain search words "waive", "failure", "violation" or "non-compliance" to assure that these indeed had to do with financial covenants violations.
} 
secured loans with ratings in the BB or B range and spreads in the neighborhood of 300 basis points. $^{19}$

In comparing the two samples, it is important to keep in mind their relative differences. The at-origination sample covers a longer period of time (loans originated 1997-2007 versus 2005-2007). However, it conditions on the presence of a loan amendment (i.e., availability of SEC filings), which effectively eliminates some smaller loans (the average loan in the atorigination sample is $\$ 560$ million while the average loan in the portfolio sample is $\$ 464$ million). Table 1, Panel B presents a more extensive description of the borrowers, using Compustat data for the fiscal year ending prior to loan origination. Looking at the portfolio sample, securitized loans and borrowers are larger than their unsecuritized counterparts on average, but not significantly different on other dimensions. In the at-origination sample, securitized loans are smaller (as a result of conditioning on amendment) but borrowers are not significantly different in size. Securitized borrowers look riskier on some dimensions, however, including leverage and interest coverage. Next we examine whether loan and borrower characteristics predict securitization in a multivariate setting.

\section{[TABLE 1]}

Table 2 examines how ex-ante loan and borrower characteristics influence the probability of securitization; this repeats the analysis in Table 1 in a multivariate setting. We estimate a probit model where the dependent variable is a dummy equal to one if a loan was securitized and zero otherwise; the independent variables are loan and borrower characteristics at origination. All regressions include lead arranger fixed effects, in addition to fixed effects for the borrower's

\footnotetext{
${ }^{19}$ Benmelech and Dlugosz (2009) find that CLOs are typically backed by collateral pools with a weighted average rating of $\mathrm{BB}-/ \mathrm{B}+/ \mathrm{B}$. Many restrict the amount of securities rated below $\mathrm{CCC}+$ to 5-7 percent of the pool, suggesting that the average loan held by a CLO has a BB or B rating.
} 
industry, credit rating at loan origination, and the year of loan origination. On balance, larger loans are more likely to be sold to CLOs, though the effect is more pronounced in the portfolio sample as expected given the sample construction. In the portfolio sample, a one standard deviation increase in the log of loan size (1.3) is associated with an 11 percentage point increase in the probability of securitization. Also in the portfolio sample, various other loan characteristics are significant in predicting securitization. LBO loans, loans to public companies, and loans with higher spreads are more likely to be sold to CLOs.

[TABLE 2]

\subsection{Hypothesis I: Does securitization predict worse future performance?}

\subsubsection{Benchmark results}

The first set of tests examines whether securitized loans are worse quality than comparable unsecuritized loans. All regressions are estimated at the loan level with lead arranger fixed effects so the coefficient on the securitization dummy can be interpreted as the marginal effect of securitization on performance among loans originated by a given bank. The atorigination sample includes loans originated between January 1997 and May 2007. The portfolio sample includes loans originated between January 2005 and July 2007. To allow for the comparison of coefficients across samples, we include two securitization dummies, Securitized and Securitized in 2005-2007, in the at-origination sample regressions. Securitized in 2005-2007 is essentially an interaction term reflecting the marginal effect for securitized loans originated between 2005 and 2007. The total effect of securitization for loans originated in 2005-2007 in the at-origination sample is given by the sum of these coefficients (Securitized and Securitized in 2005-2007). For each regression on this sample, we provide the $p$-value corresponding to the statistical test that the sum of these coefficients is equal to zero (i.e., the null hypothesis that 
there is no difference in the performance of securitized and unsecuritized loans originated during the later period). Each specification includes year fixed effects, so we control for level effects in 2005, 2006 and 2007 individually. We also include industry effects when the dependent variable is not already industry-adjusted and fixed effects for credit ratings at loan origination.

Other controls include log of loan maturity measured in years, the log of loan size measured in millions of dollars, and the loan's spread over LIBOR contracted at loan origination and measured in basis points. (Our results are not sensitive to whether we use $\log$ transformations of particular explanatory variables or not.) The spread contracted at loan origination controls for the risk that is priced by a broad investor base at that time. For example, a loan originated in 2006 paying 150 bps over LIBOR could be classified as risky or highly levered even if no other information were available. If we ignore the contracted spread we might miss this fact. ${ }^{20}$ We also include an indicator variable equal to one if the contract includes performance pricing. Performance pricing allows for the original spread to be adjusted based on the financial performance of the borrower; presence of the performance pricing feature is likely to indicate borrowers with more transparent accounting performance. When looking at loan prices (a facility-level variable) we include facility-level size controls. Notice that by construction our sample only includes term loan facilities. ${ }^{21}$ Throughout the analysis we control for loan purpose, specifically we look at whether the loan was issued to fund an LBO, a merger or acquisition, or debt repayment (i.e., recapitalization). The omitted categories of loan

\footnotetext{
${ }^{20} \mathrm{We}$ also run our benchmark results excluding the spread from the right hand side, however, this change has no effect on the results for $\mathrm{H} 1$ and limited effect on H2. More broadly, ratings (or any other observable information) are not a sufficient statistic for explaining the spreads. Ivashina (2009) models spreads in which she controls for ratings any many other observables at the time of origination; the R-squared of such model is approximately 0.55 .

${ }^{21}$ Holdings of revolving lines by CLOs are very rare (we confirm this in the portfolio sample). Furthermore because our measure of securitization is a dummy it would be very unlikely that in a given loan package CLOs hold a revolving line but not a term loan.
} 
purpose-working capital and general corporate purpose-can be broadly grouped as real investments.

Table 3 examines whether securitized and unsecuritized loans perform differently on the secondary market post-origination, controlling for observables. The dependent variable is the percentage change in the bid price in a window around origination. The key explanatory variables are the securitization indicators: Securitized, and Securitized in 2005-2007. The results suggest that securitized loans originated before 2005 outperform unsecuritized loans from the same lead bank on the secondary market. The outperformance is only significant in the second year, when these loans experience price appreciation 4.8 percentage points greater than that of unsecuritized loans on average. The results are mixed for loans originated between 2005 and 2007, depending on the sample. In the at-origination sample, there appears to be a trend of deterioration over time, as evidenced by the negative coefficients on Securitized in 2005-2007, however this is only a marginal effect. The total effect of securitization for loans originated 2005-2007 in this sample is given by the sum of the securitization coefficients (Securitized + Securitized in 2005-2007). As shown by the $p$-value for the $F$-test, we cannot reject the hypothesis that the sum of these coefficients is equal to zero. In other words, securitized loans issued during the late period do not underperform in the at-origination sample. However, they do underperform in the portfolio sample. In the portfolio sample, securitized loans experience a decrease in price 2.0 percentage points greater than comparable unsecuritized loans in the same window. These differences are economically significant since the mean change in loan price over the horizon is $3 \%$ for the at-origination sample and $-6 \%$ for the portfolio sample and the standard deviations are $11 \%$ and $13 \%$ respectively. However, given the significant drop in liquidity in the secondary loan market around the financial crisis, we cannot definitively attribute the 
underperformance of securitized loans to deterioration in fundamentals. For additional evidence, we turn to other measures.

\section{[TABLE 3]}

In Table 4, we examine whether securitized loans are more likely to be downgraded or less likely to be upgraded than comparable unsecuritized loans originated by the same lead bank. Panel A presents the downgrade results and Panel B presents the upgrade results. In specifications for the at-origination sample, Securitized in 2005-2007 is an interaction term between Securitized and the 2005-2007 loan-origination window. Due to the issues with interaction effects in nonlinear models (Ai and Norton, 2003)—specifically that the coefficients on interaction terms cannot be interpreted as marginal effects and may even have the opposite sign-all regressions are estimated with a linear model to maintain consistency across specifications. Controlling for loan and borrower characteristics at origination, we find no support for the hypothesis that securitization predicts deterioration in credit ratings for loans originated before 2005. As before, the results are mixed for loans originated between 2005 and 2007. The results are statistically significant only in the portfolio sample, indicating that for loans originated between 2005 and 2007, downgrades are more likely particularly in the second year following loan origination. Our results suggest that loans securitized in 2005-2007 are 12 percentage points more likely to be downgraded in a two year window after origination than comparable unsecuritized loans. This is economically significant because the unconditional probability of a downgrade over this period is $25 \%$. Although upgrades appear to be less likely for the same sub-sample, the estimates are not statistically different from zero. However, upgrades are significantly less likely for loans originated in 2005-2007 in the at-origination sample. 


\section{[TABLE 4]}

Our third measure of performance is CDS spreads. The dependent variable in Table 5 is the percentage change in borrower's CDS spreads in a given window following loan origination. A positive coefficient indicates an increase in CDS spreads or deterioration in credit quality. We omit industry fixed effects in the at-origination sample due to the small sample size. Controlling for the borrower's credit rating and lagged CDS volatility, we find that securitized loans originated before 2005 experience similar performance to unsecuritized loans. ${ }^{22}$ The results for the subset of loans originated between 2005 and 2007 are mixed with evidence of outperformance, although not consistently across the two samples. In the at-origination sample, borrowers with securitized loans originated 2005-2007 experience a decline in CDS spreads that is 221 percentage points larger than that of comparable unsecuritized borrowers. This seemingly outsized differential is likely the product of the small sample and the disruption in CDS markets due to heightened concerns about counterparty credit risk during the crisis. Between mid-2007 and year-end 2008, the median CDS spread for speculative grade companies increased from under 250 bps to nearly 750 bps. Roughly $10 \%$ of the 44 companies in our regression experienced an increase in CDS spreads of more than $100 \%$ during the window under examination. While these large changes in spreads are not likely to be driven by data errors (Markit requires a minimum number of quotes to report a spread) the magnitude of the effect may reflect factors other than the credit quality of the underlying companies and limit the interpretive power of the result.

\footnotetext{
${ }^{22}$ We do not control for Compustat variables here because conditioning on companies being public would reduce the sample. One of the main benefits of using CDS spreads is that they exist for private companies.
} 
Next we examine another measure of default probability that gets around the issues with CDS spreads: implied default probability from a reduced-form Merton (1974) model. Table 6 compares changes in one-year implied default probabilities for securitized and unsecuritized borrowers around loan origination. Again we find no significant difference in performance between securitized and unsecuritized borrowers in either sample regardless of the period in which the loan was originated.

\section{[TABLES 5\& 6]}

None of these performance measures is perfect, however taken together the four different measures provide a comprehensive overview of performance. To summarize, controlling for observables at the time of loan origination, securitized loans originated before 2005 perform similarly to other institutional loans from the same lead arranger that are unsecuritized. We find some evidence that securitized loans originated in the later period underperform over the two year horizon, but only in the portfolio sample (as discussed earlier, this sample is sensitive to type II error). There is no evidence of underperformance for securitized loans originated between 2005-2007in the at-origination sample. Furthermore, even for the portfolio sample, results across different performance measures do not consistently indicate underperformance.

The results indicate that agency problems in loan securitization may be less important than commonly believed. Despite the fact that CLOs are subject to additional layers of agency and adverse selection problems, their investment choices appear no different than the investment choices of other non-lending institutions (in terms of ex-post performance). The results on securitized loans originated during the boom years of 2005-2007 are mixed, depending on the sample and the performance metric. We find some weak evidence of underperformance in loan prices and credit ratings. The fact that the performance difference is concentrated among loans 
originated in the 2005-2007 and in the second year performance window raises issues about overheated market conditions and the passive nature of CLOs and not necessarily incentives for securitization of corporate loans per se. We interpret these findings as indicative of the contribution of CLOs to overall demand pressure by institutional investors that led to a deterioration in lending standards (e.g., Ivashina and Sun, 2011a) and was also associated with shrinking loan retention by originating banks (see Ivashina and Scharfstein, 2010 and, more recently, Bord and Santos, 2011).

\subsubsection{Addressing selection}

In both samples, we limit attention to loans that are likely candidates for securitization to assure that securitized and unsecurititized loans are comparable. However, in the absence of a clear mechanism that explains the selection of loans into CLOs there might be some residual concern that the treatment and control subsets are not comparable. To address this issue in Table 7 we explore a quasi-experimental setting, where we rely on temporary imbalances between CLO demand for loans and loan originations. The argument is that CLOs face an investment constraint which they cannot smooth over time. We consider several proxies for the aggregate imbalance between supply and demand at the quarterly frequency: (i) CLO issuance (CLO fund flow); (ii) the change in the CLO pipeline, which reflects CLO volume that is not yet closed; (iii) CLO issuance scaled by total term loan issuance. For robustness, we also look at the overall net cash flow into institutional accounts scaled by total term loan issuance. An increase in any of these variables represents an increase in either CLO demand or institutional demand. CLO flow data is compiled using CLO calendars published by Reuters Gold Sheets. Institutional fund flow data is from S\&P LCD Quarterly Review covering activity in the leveraged loan market. Total 
term loan issuance is constructed using DealScan. Both types of fund flow data are available from 2001 through 2009.

Aggregate trends, in particular at the overall institutional level, are likely to be exogenous to the loan selection made by any individual CLO. The basic intuition is that an increase in aggregate demand for loans should push CLOs to invest in loans that would typically be held by other institutional investors. If the loans typically held by CLOs are of a different quality (than unsecuritized loans), we would expect the marginal loans purchased by CLOs during these times to differ from the average quality of CLO collateral. (Given the exogenous nature of the demand proxies, the quality of the overall pool of potentially securitizable loans is likely to be unchanged; in other words, under pressure, CLOs reach into the pockets of other institutional investors.) Table 7 replicates the tests presented for the first hypothesis (Tables 3-6) with the alternative proxies for CLO demand for loans. In addition to controls used in the analysis in Tables 3 to 6 we include a demand proxy and its interaction with the Securitized dummy; these interaction terms are the coefficients of interest. Coefficients on benchmark controls and fundflow proxies are omitted for compactness of presentation. Because we use several proxies for high CLO demand, the 2005-2007 interaction term-i.e., an indicator for the height of the securitization boom - would be redundant.

Out of 40 coefficients of interest (40 interaction terms from 40 different regressions) 36 are not statistically different from zero. This indicates that when temporarily higher loan demand by CLOs pushes them to invest in loans that would typically be held by other institutional investors, these loans are no better or worse than average securitized loan. Among the significant coefficients, three out of four actually indicate that securitized loans are on average better quality than unsecuritized loans because their marginal investments during times of demand pressure 
underperform. This evidence is consistent with the findings in Tables 3 through 6; loans with CLO investors are no different than loans held by other institutional investors. ${ }^{23}$

\section{[TABLE 7]}

\subsection{Hypothesis II: Does securitization by the originator predict worse future performance?}

In this section, we examine the performance of a subset of securitized loans for which we expect agency problems to be particularly pronounced. Adverse selection problems could be particularly acute when banks engage on both sides of the loan market - originating loans and underwriting CLOs that purchase loans for collateral. This presents the greatest opportunity for a bank to sell poor quality loans to a CLO, because there is one less monitor of loan quality at the CLO level.

Since we cannot identify the seller of loans in the secondary market, we limit the sample to primary market purchases for this part of the analysis (hence, we only use the information in Dealscan for the at-origination sample). This ensures that the loan's lead arranger sold the loan to the CLO. We separate primary market purchases of loans by CLOs into two groups: cases where the loan arranger is the CLO underwriter (same bank) and cases where the loan arranger is different from the CLO underwriter (different bank). Then we compare post-origination borrower performance across the two types of loans, within a given CLO portfolio, using three different performance measures. We omit CDS tests because the sample of same bank loan x CLO observations with CDS spreads is small. Note that in order to compare the performance of different loans within the same CLO portfolio, we are using a (loan x CLO) dataset. In all

\footnotetext{
${ }^{23}$ In addition to the results reported in Table 7, we also look within the sample of the loans held by CLOs and test whether, controlling for loan size, the number of CLOs in the syndicate or the share of the loan allocated to CLOs predicts future loan performance. Because corporate loans are not fully securitized and are held by other investors including banks, we expect that larger CLO presence will be associated with worse quality loans. However, the intensity of CLO investment has no predictive power for performance in our regressions.
} 
regressions, we include CLO fixed effects and cluster standard errors by loan. Given that our comparison is between two groups of securitized loans, it is unlikely that the results are driven by unobservable factors that might explain why some loans are securitized. Thus, by studying the intensive margin of securitization we alleviate some of the concerns about the endogeneity of the securitization decision itself. Additionally, we only include CLOs for which we have a clearly identified underwriter.

Table 8 examines secondary market loan performance across both types of loans. As before, the dependent variable is the percentage change in the mid-quote (the average of the bid and ask quotes) in a window around origination. On average, loans purchased from the CLO underwriter experience more price appreciation on the secondary market after loan origination than other loans in the same CLO portfolio. In the year one, same bank loans originated before 2005 experience a 0.1 percentage point larger price appreciation; in year two, it is a 0.9 percentage point differential. Same bank loans originated between 2005 and 2007 seem to underperform same bank loans originated between 1997 and 2004 (i.e., marginal effect for 20052007) in year two. However, the total effect for loans originated in the late period is given by the by the sum of the Same bank and Same bank in 2005-2007 coefficients. As shown by the $p$-value for the $F$-test, we cannot reject the hypothesis that same bank loans originated during this period perform the same as other securitized loans. Also, the mean one-year price change in our sample is around $1-2 \%$ with a standard deviation of around $10 \%$. While some performance differences are statistically significant, they do not appear strongly economically significant, especially in year one.

Table 9 examines whether the sale of a loan by its lead arranger into one of its own CLOs predicts downgrades or upgrades in loan ratings. Panel A presents the downgrade results and 
Panel B presents the upgrade results. The signs on the same bank coefficients indicate that in the two years after origination, borrowers whose loans are sold to CLOs underwritten by their lead arranger are more likely to be downgraded and less likely to be upgraded than other loans in the same CLO. Although the economic magnitudes appear to be non-trivial, the results are not statistically significant regardless of the loan vintage.

In Table 10, we examine implied default probabilities from the reduced-form Merton model. While the number of observations in the sample is large, the number of same bank loans in the sample is relatively small (only around 150) and the performance comparison is made among loans within a given CLO portfolio. For this reason we have to drop a set of fixed effects in order to estimate the regression. We drop year fixed effects because the majority of loans acquired by a given CLO tend to be acquired over a limited period of years around CLO issuance. So the within-portfolio comparison would naturally help to limit the vintage of loans being compared. The results show that companies whose loans are bought by CLOs underwritten by their lead arranger outperform other borrowers whose loans are held in the same portfolio over a one-year horizon and underperform over a two-year horizon. While the differences seem economically large (the average change in default probability in our sample is $2.4 \%$ ), they are again statistically not different from zero regardless of the loan vintage.

\section{[TABLES 8 -10]}

Overall, the evidence rejects the hypothesis that banks that participate on both sides of the market, originating loans and underwriting CLOs, exploit their private information to the detriment of CLO managers. By some measures, loans purchased from the CLO underwriter and originated before 2005 outperform other loans in the same portfolio.

\subsection{Robustness Check: Loan covenant violations}


As a robustness check, we examine one additional measure of loan performance: the frequency of financial covenant violations. Table 11 summarizes covenant violations for the samples that correspond to the two hypotheses tested in the paper. Covenant violations are rare for the loans in our sample: only $6 \%$ of loans in the at-origination sample and less than $1 \%$ of loans in the portfolio sample experienced a covenant violation. We present univariate results because of the large number of fixed effects required in our benchmark specifications. As shown in the first four columns of the table, securitized loans are no more likely to experience covenant violations than unsecuritized loans in both samples regardless of the loan vintage. Naturally, the probability that a poorly performing borrower violates a loan covenant depends on the nature of the covenant package included in the loan. The disappearance of covenants from loan contracts during the recent boom was well documented in media reports and industry newsletters. We find no evidence that securitized loans have fewer covenants except in one case: securitized loans originated pre-2005 (arguably before cov-lite loans became popular) have 0.28 fewer financial covenants on average. This raises the possibility that the reason why securitized loans originated before 2005 do not violate covenants at a higher rate than their unsecuritized counterparts could be that they have fewer covenants to begin with. However, in a multivariate setting with our standard controls, there is no significant difference in the incidence of covenants. In summary, securitized loans do not appear to violate loan covenants at a higher frequency than unsecuritized loans which supports the results from the other performance regressions.

$$
\text { [TABLE 11] }
$$

\section{Conclusion}

Using a unique dataset on loans used as CLO collateral we provide the first insight on whether securitization led to risky lending in the corporate loan market. Contrary to the adverse 
selection hypothesis, we find that securitized loans were of similar quality as unsecuritized loans sold to other institutional investors. Our paper highlights the uniqueness of securitization in the corporate loan market. In particular, corporate loans purchased by CLOs are syndicated. A securitized loan that is held by CLOs can simultaneously be held by mutual funds, hedge funds and other non-bank financial institutions. In general, to be able to attribute underperformance results to incentives within CLOs, we must understand incentives not only of originating lenders but also of other investors in the lending syndicate.

Our findings indicate that adverse selection in the securitization of corporate loans is at best weak. These results stand in sharp contrast to the findings on mortgage securitization and provide a broad insight about structured finance products: Adverse selection is not an inevitable consequence of securitization. "Skin in the game" on the part of the originating lender and distribution among investors may be sufficient to alleviate concerns about adverse selection in collateral pools. This is consistent with the risk retention requirements like those outlined in the Dodd-Frank Act. However, another important point that emerges from our paper is that there are vast differences in the securitization process, and the attendant incentive problems, across structured asset classes. To that extent, the one-size-fits-all approach to risk retention taken in the financial reform bill could miss its mark and have the unintended effect of limiting the supply of credit to firms. 


\section{References:}

Ai, C., Norton, E.C., 2003. Interaction Terms in Logit and Probit Models. Economics Letters 80, 123-129.

Altman, E., 1968. Financial Ratios, Discriminant Analysis and the Prediction of Corporate Bankruptcy. Journal of Finance 23, 589-609.

Altman, E., Gande, A., Saunders, A., 2010. Bank Debt versus Bond Debt: Evidence from Secondary Market Prices. Journal of Money, Credit and Banking 42, 755-767.

Bharath, S., Shumway, T., 2008. Forecasting Default with the Merton Distance to Default Model. Review of Financial Studies 21, 1339-1369.

Benmelech, E., Dlugosz, J., 2009. The Alchemy of CDO Credit Ratings. Journal of Monetary Economics 56, 617-634.

Bord, V. and Santos, J., 2011. Did the Rise of CLOs lead to riskier lending? Unpublished working paper. Federal Reserve Bank of New York.

Coval, J., Jurek, J., Stafford, E., 2009. The Economics of Structured Finance. Journal of Economic Perspectives 23, 3-25.

Drucker, S., Puri, M., 2009. On Loan Sales, Loan Contracting and Lending Relationships. Review of Financial Studies 22, 2635-2672.

Drucker, S., Mayer, C., 2008. Inside Information and Market Making in Secondary Mortgage Markets. Unpublished working paper. Columbia Business School, The Paul Milstein Center for Real Estate.

Fabozzi, F.J., Goodman, L., Lucas, D., 2006. Collateralized Debt Obligations. John Wiley \& Sons, Inc., New Jersey.

Gupta, A., Singh, A., Zebedee, A., 2008. Liquidity in the Pricing of Syndicated Loans. Journal of Financial Markets 11, 339-376.

Ivashina, V., 2009. Asymmetric Information Effects on Loan Spreads. Journal of Financial Economics 92, 300-319.

Ivashina, V., Scharfstein, D., 2010, Loan Syndication and Credit Cycles. American Economic Review (Papers and proceedings) 100, 57-61.

Ivashina, V., Sun, Z., 2011. Institutional Demand Pressure and the Cost of Corporate Loans. Journal of Financial Economics 99, 500-522. 
Ivashina, V., Sun, Z., 2011. Institutional Stock Trading on Loan Market Information. Journal of Financial Economics 100, 284-303.

Keys, B., Mukherjee, T., Seru, A., Vig, V., 2010. Did Securitization Lead to Lax Screening? Evidence From Subprime Loans. Quarterly Journal of Economics 125, 307-362.

Loan Syndication and Trading Association, 2007. The Handbook of Loan Syndication and Trading. Loan Syndication and Trading Association, New York, McGraw-Hill, New York.

Merton, R., 1974. On the Pricing of Corporate Debt: The Risk Structure of Interest Rates. Journal of Finance 29, 449-470.

Nadauld, T., Sherlund, S., 2009. The Role of the Securitized Process in the Expansion of Subprime Credit. Unpublished working paper. Ohio State University, Charles A. Dice Center for Research in Financial Economics.

Nadauld, T., Weisbach, M., 2011. Did Securitization Affect the Cost of Corporate Debt? Journal of Financial Economics, forthcoming.

Shivdasani, A., Wang, Y., 2009. Did Structured Credit Fuel the LBO Boom? Unpublished working paper. University of North Carolina, Chapel Hill.

Standard \& Poor's, 2002. Global Cash Flow and Synthetic CDO Criteria. Standard \& Poor's, New York.

Standard \& Poor's, 2006. A Guide to the Loan Market. Standard \& Poor's, New York.

Tavakoli, J., 2003. Collateralized Debt Obligations and Structured Finance: New Developments in Cash and Synthetic Securitization. John Wiley \& Sons, Inc., New Jersey. 
Fig. 1. CLO issuance. The figure is compiled using weekly CLO calendars published by Reuters, Gold Sheets. The pipeline indicates CLOs that have not yet closed (i.e., been fully invested.)

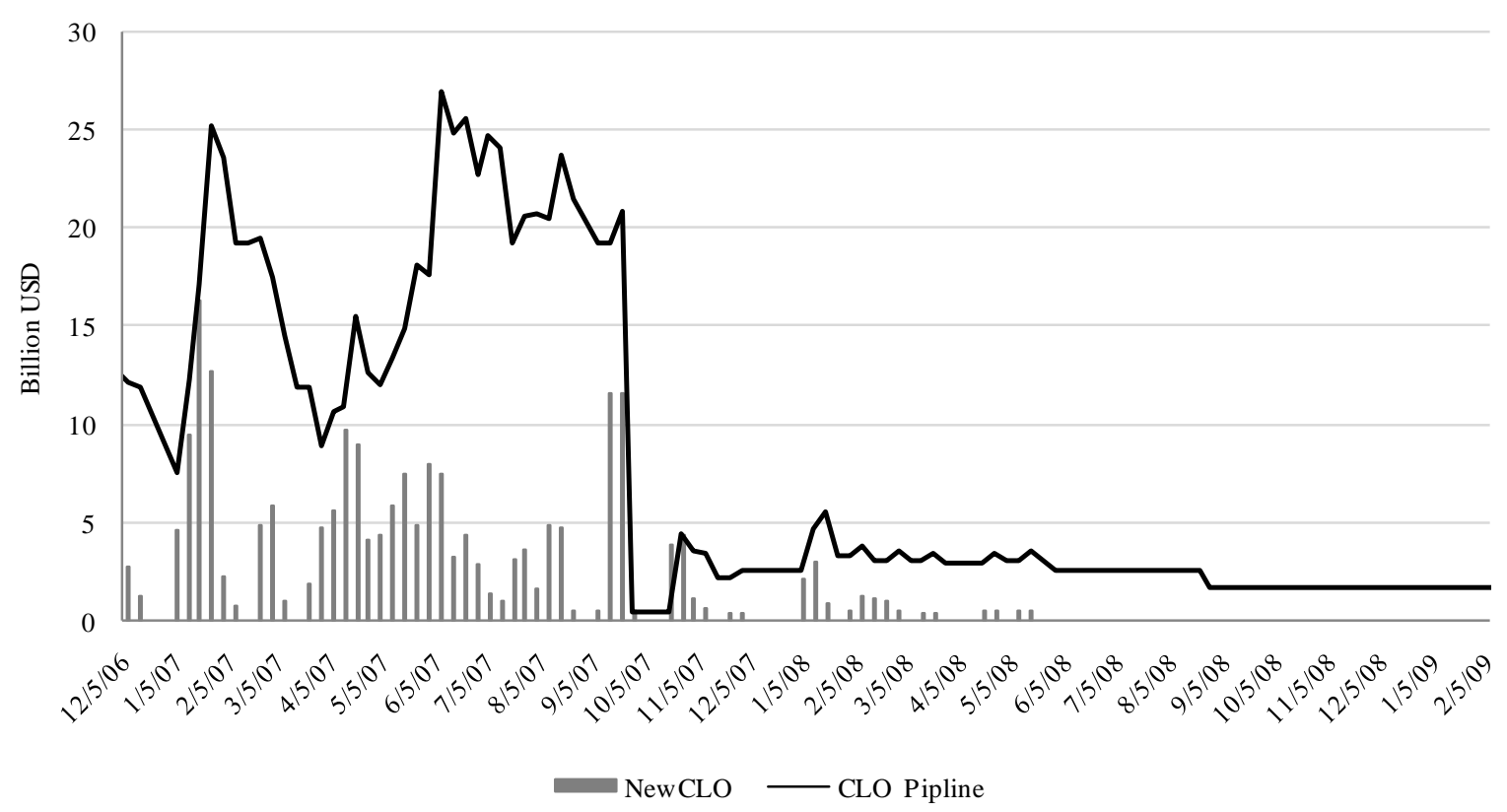


Fig. 2. Quarterly global CDO issuance, 2005-2008. This figure is compiled using issuance data published by the Securities Industry and Financial Markets Association (SIFMA). Structured finance corresponds to global CDO issuance backed by collateral that is itself structured (e.g., residential and commercial mortgages-backed securities, asset-backed securities, credit default swaps, or other CDOs). For example, mortgages are usually pooled into pass-through securities before they are purchased by CDOs.

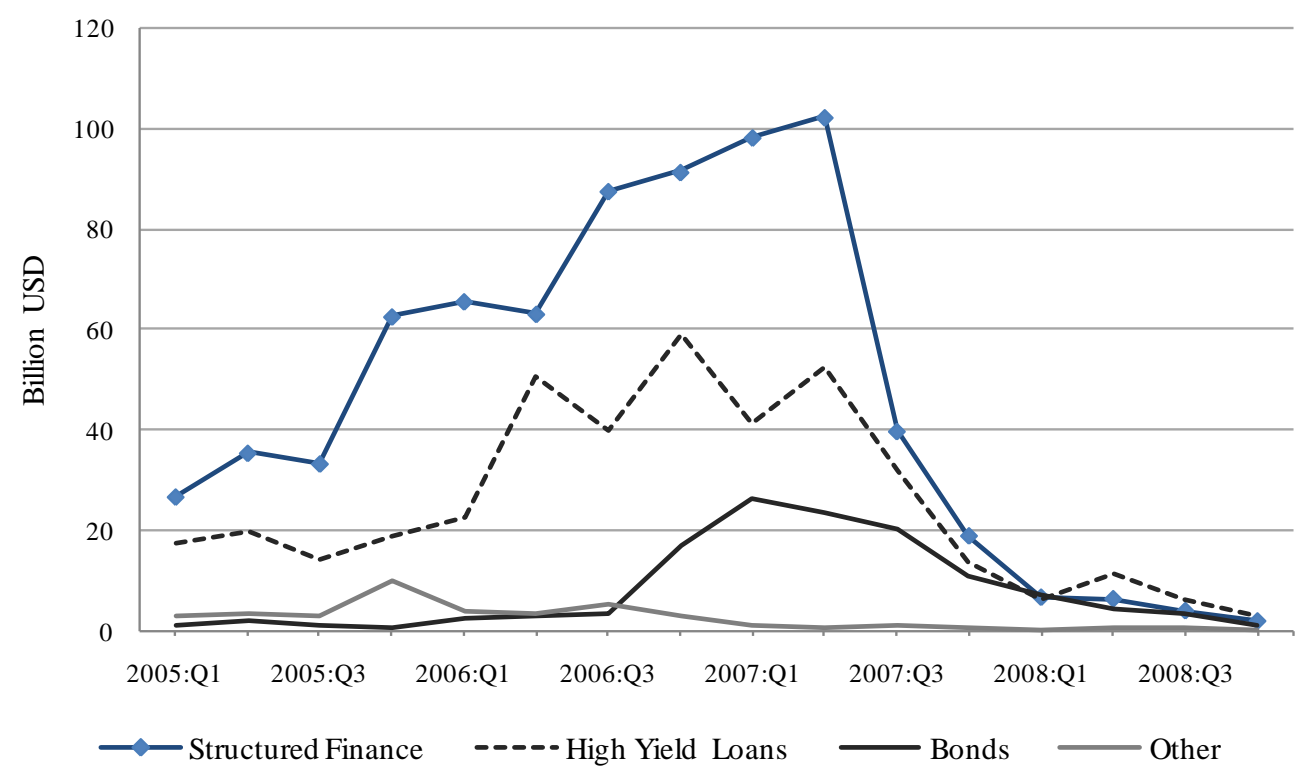


Fig. 3. CLO Structuring. This figure illustrates different steps involved in the securitization of corporate loans and highlights involvement of different agents (CLO manager, Underwriter, etc.) during the separate stages of the process.

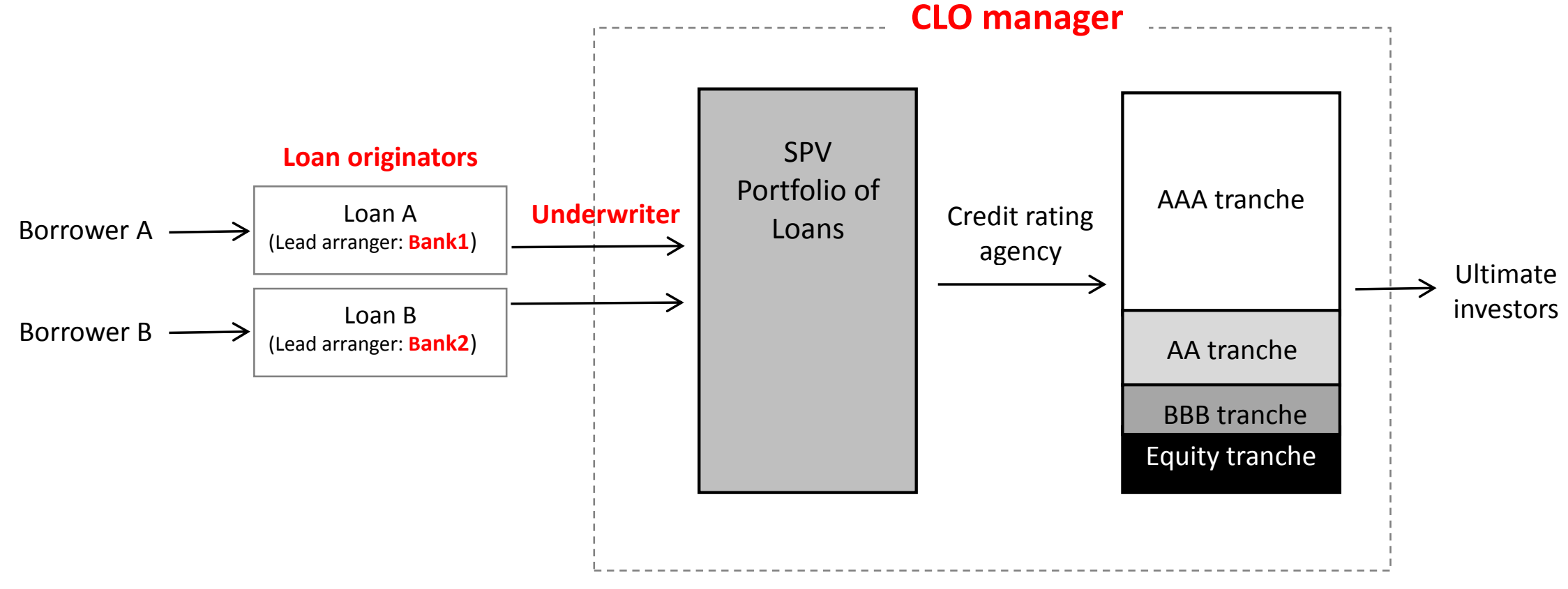




\section{Table 1}

Summary statistics

This table reports summary statistics for both samples. The at-origination sample includes loans originated between 1997 and May 2007. The portfolio sample includes loans originated between January 2005 and July 2007. Statistics are also split based on the two main hypotheses tested in the paper. Same bank (H2) indicates loans that appeared in a CLO underwritten by their lead arranger. Loan variables are constructed using DealScan. Minimum assignment is the minimum investment for syndicate participants. Sales at close is taken at the time the loan is closed. Leverage (loan) is the size of the loan divided by the borrower's sales at close. All-in-drawn spread is defined as total (fees and interest) annual spread paid over LIBOR for each dollar drawn down from the loan net of upfront fees. Senior debt rating and Loan rating come from Reuters Gold Sheets (compiled from S\&P and Moody's). Performance pricing dummy indicates that the spread on the loan is tied to the firm's financial indicators. LBO, M\&A and Debt repayment dummies indicate the purpose of the loan. In Panel B, financial data corresponds to the fiscal year that ended just prior to loan origination. Industries are measured at the 2-digit SIC code level and industry adjusted figures have the industry median subtracted for the corresponding fiscal year. Compustat variables: Leverage is Total Long-Term Debt plus Debt in Current Liabilities divided by Total Assets. Loan size/Assets is the loan size from DealScan divided by Compustat's Total Assets. Interest coverage is EBITDA divided by Interest and Related Expense. Return on assets (ROA) is EBITDA divided by Total Assets. $Q$ is [Assets + Market Value of Equity - Book Value of Equity - Deferred Taxes]/Assets. Z-score is defined as in Altman (1968). In Panel B, the number of observations corresponds to the loans for which pre-origination assets is available. All dollar figures are measured in millions.

Panel A: Loan terms

\begin{tabular}{|c|c|c|c|c|c|c|c|c|c|c|}
\hline & & \multicolumn{6}{|c|}{ H1: Effects of securitization } & \multirow{2}{*}{\multicolumn{3}{|c|}{$\frac{\text { H2: Effects of underwriting }}{\text { At-origination sample }}$}} \\
\hline & & \multicolumn{3}{|c|}{ At-origination sample } & \multicolumn{3}{|c|}{ Portfolio sample } & & & \\
\hline & & \multicolumn{2}{|c|}{ Securitized: } & \multirow{2}{*}{$\begin{array}{l}\text { Diff. } \\
t \text {-stat }\end{array}$} & \multicolumn{2}{|c|}{ Securitized: } & \multirow{2}{*}{$\begin{array}{l}\text { Diff. } \\
t \text {-stat }\end{array}$} & \multicolumn{2}{|c|}{ Same bank: } & \multirow{2}{*}{$\begin{array}{l}\text { Diff. } \\
t \text {-stat }\end{array}$} \\
\hline & & Yes & No & & Yes & No & & Yes & No & \\
\hline Number of loans & & 302 & 185 & & 1,084 & 2,508 & & 104 & 198 & \\
\hline Loan size & Mean & 522 & 623 & 1.96 & 738 & 346 & 9.39 & 614 & 474 & 2.61 \\
\hline Minimum assignment & Mean & 3.5 & 3.4 & 0.56 & 3.3 & 3.5 & 1.33 & 3.1 & 3.8 & 2.42 \\
\hline Sales at loan close & Mean & 1,788 & 1,680 & 0.38 & 2,617 & 1,280 & 3.51 & 1,711 & 1,831 & 0.30 \\
\hline Leverage (loan) & Mean & 0.72 & 0.87 & 1.65 & 1.09 & 1.02 & 0.93 & 0.70 & 0.73 & 0.35 \\
\hline All-in-drawn spread (bps) & Mean & 304 & 313 & 0.81 & 288 & 278 & 1.82 & 289 & 313 & 1.62 \\
\hline All-in-drawn spread (bps) & Median & 275 & 300 & & 275 & 250 & & 275 & 300 & \\
\hline Senior debt rating (borrower) & Mean & $\mathrm{B}+/ \mathrm{B}$ & $\mathrm{B}+/ \mathrm{B}$ & 1.58 & $\mathrm{~B}+/ \mathrm{B}$ & $\mathrm{B}+$ & 4.32 & $\mathrm{~B}+$ & $\mathrm{B}+/ \mathrm{B}$ & 1.79 \\
\hline Senior debt rating (borrower) & Median & $\mathrm{B}+$ & $\mathrm{B}+$ & & B & B & & $\mathrm{B}+$ & $\mathrm{B}+$ & \\
\hline Loan rating & Mean & $\mathrm{BB}-/ \mathrm{B}+$ & $\mathrm{BB}-/ \mathrm{B}+$ & 1.29 & $\mathrm{~B}+$ & $\mathrm{BB}-/ \mathrm{B}+$ & 3.27 & $\mathrm{BB}-/ \mathrm{B}+$ & $\mathrm{BB}-/ \mathrm{B}+$ & 0.91 \\
\hline Loan rating & $25^{\text {th }} \%$ & BB- & BB- & & BB- & BB- & & BB- & BB- & \\
\hline Loan rating & Median & $\mathrm{BB}-/ \mathrm{B}+$ & BB- & & $\mathrm{B}+$ & $\mathrm{B}+$ & & BB- & $\mathrm{B}+$ & \\
\hline Loan rating & $75^{\text {th }} \%$ & $\mathrm{~B}+$ & $\mathrm{B}+$ & & B & B & & $\mathrm{B}+$ & $\mathrm{B}+$ & \\
\hline Perf. pricing (dummy) & Mean & 0.38 & 0.40 & 0.52 & 0.14 & 0.11 & 2.14 & 0.41 & 0.36 & 0.95 \\
\hline LBO loan (dummy) & Mean & 0.44 & 0.29 & 3.35 & 0.61 & 0.39 & 12.5 & 0.45 & 0.43 & 0.38 \\
\hline M\&A loan (dummy) & Mean & 0.13 & 0.18 & 1.80 & 0.10 & 0.12 & 1.47 & 0.14 & 0.12 & 0.70 \\
\hline Debt repayment loan (dummy) & Mean & 0.09 & 0.13 & 1.75 & 0.03 & 0.01 & 3.93 & 0.05 & 0.12 & 1.94 \\
\hline
\end{tabular}


Table 1 - continued

Panel B: Borrower characteristics (sample matched to Compustat)

\begin{tabular}{|c|c|c|c|c|c|c|c|c|c|c|c|c|c|c|}
\hline & \multicolumn{7}{|c|}{ At-origination sample } & \multicolumn{6}{|c|}{ Portfolio sample } & \multirow{3}{*}{$\begin{array}{l}\text { Diff. } \\
t \text {-stat }\end{array}$} \\
\hline & \multicolumn{3}{|c|}{$\begin{array}{l}\text { Securitized loans } \\
\quad(\text { Obs. }=220)\end{array}$} & \multicolumn{3}{|c|}{$\begin{array}{c}\text { Unsecuritized loans } \\
\text { (Obs.=166) }\end{array}$} & \multirow{2}{*}{$\begin{array}{l}\text { Diff. } \\
t \text {-stat }\end{array}$} & \multicolumn{3}{|c|}{$\begin{array}{l}\text { Securitized loans } \\
\quad(\text { Obs. }=347)\end{array}$} & \multicolumn{3}{|c|}{$\begin{array}{c}\text { Unsecuritized loans } \\
(\text { Obs. }=634)\end{array}$} & \\
\hline & Median & Mean & SD & Median & Mean & $\mathrm{SD}$ & & Median & Mean & SD & Median & Mean & $\mathrm{SD}$ & \\
\hline Total assets & 944 & 2,184 & 3,742 & 804 & 2,107 & 4,179 & 0.19 & 1,253 & 8,180 & 46,292 & 882 & 3,140 & 8,216 & 2.67 \\
\hline Net sales & 782 & 2,022 & 3,406 & 611 & 1,642 & 2,790 & 1.17 & 1,110 & 4,405 & 15,641 & 698 & 2,447 & 8,141 & 3.51 \\
\hline Market cap. & 576 & 1,144 & 2,206 & 603 & 1,314 & 2,075 & 0.66 & 1,048 & 2,326 & 3,568 & 800 & 2,543 & 5,737 & 0.57 \\
\hline Loan size/Assets & 0.42 & 0.55 & 0.50 & 0.44 & 0.63 & 0.63 & 1.41 & 0.49 & 11.2 & 115 & 0.38 & 3.18 & 50.9 & 1.51 \\
\hline Leverage & 0.51 & 0.53 & 0.36 & 0.42 & 0.44 & 0.29 & 2.70 & 0.43 & 0.56 & 1.53 & 0.37 & 0.48 & 1.25 & 0.92 \\
\hline Interest coverage & 2.78 & 5.60 & 11.9 & 3.06 & 13.6 & 60.7 & 1.87 & 3.53 & 24.8 & 249 & 4.39 & 31.1 & 431 & 0.24 \\
\hline Return on assets & 0.12 & 0.12 & 0.07 & 0.12 & 0.12 & 0.09 & 0.11 & 0.11 & 0.07 & 0.85 & 0.12 & 0.09 & 0.65 & 0.41 \\
\hline Z-score & 2.12 & 4.15 & 14.7 & 2.26 & 9.70 & 40.0 & 1.54 & 2.63 & 13.7 & 115 & 2.95 & 19.4 & 113 & 0.62 \\
\hline Q & 1.33 & 1.50 & 0.62 & 1.41 & 1.54 & 0.68 & 0.42 & 1.60 & 2.15 & 3.80 & 1.53 & 2.07 & 3.31 & 0.32 \\
\hline Return on equity & 0.07 & 0.01 & 1.23 & 0.07 & 0.55 & 4.03 & 1.90 & 0.09 & 0.01 & 3.05 & 0.10 & -0.03 & 2.34 & 0.20 \\
\hline PPE/Assets & 0.44 & 0.52 & 0.36 & 0.42 & 0.50 & 0.34 & 0.73 & 0.44 & 0.53 & 0.43 & 0.46 & 0.55 & 0.41 & 0.59 \\
\hline Leverage (ind. adj.) & 0.23 & 0.27 & 0.37 & 0.17 & 0.21 & 0.29 & 1.87 & 0.21 & 0.33 & 1.54 & 0.14 & 0.26 & 1.25 & 0.79 \\
\hline Interest coverage (ind. adj.) & -0.31 & 2.30 & 11.7 & 0.10 & 10.3 & 60.3 & 1.88 & -0.89 & 20.0 & 250 & -0.45 & 25.9 & 433 & 0.23 \\
\hline Return on assets (ind. adj.) & 0.04 & 0.05 & 0.10 & 0.03 & 0.06 & 0.10 & 0.06 & 0.02 & -0.02 & 0.86 & 0.02 & 0.01 & 0.66 & 0.48 \\
\hline Z-score (ind. adj.) & -0.92 & 0.71 & 14.8 & -1.26 & 5.60 & 40.0 & 1.36 & -1.28 & 9.41 & 115 & -0.93 & 15.0 & 113 & 0.61 \\
\hline
\end{tabular}




\section{Table 2}

Determinants of securitization: Loan and borrower characteristics at origination

This table examines the impact of loan and borrower characteristics on the probability that a loan is sold to a CLO. The dependent variable is a dummy that equals 1 if a loan was sold to a CLO and 0 if not. The at-origination sample includes loans originated between 1997 and May 2007. The portfolio sample includes loans originated between January 2005 and July 2007. Borrower financials are taken from Compustat for the fiscal year ending prior to loan origination and industry adjustment is done at the 2-digit SIC level. The Compustat dummy equals 1 when a company has pre-origination data available in Compustat. Other variable definitions are the same as in Table 1. All specifications include fixed effects for the year of loan origination, the borrower's industry (2-digit SIC code) and rating at origination, and the identity of the loan lead arranger. We use the most granular rating information; e.g., we include separate dummies for $\mathrm{BB}+, \mathrm{BB}$, and BB-. Rating fixed effects are relative to the omitted category unrated. The coefficients shown are marginal effects.

Standard errors are clustered by loan lead arranger in all specifications. Significance at the $1 \%, 5 \%$, and $10 \%$ levels is indicated by ${ }^{* * *}{ }^{* *}$, and ${ }^{*}$, respectively.

\begin{tabular}{|c|c|c|c|c|c|c|c|c|c|c|c|c|}
\hline & \multicolumn{6}{|c|}{ At-origination sample } & \multicolumn{6}{|c|}{ Portfolio sample } \\
\hline & Coeff. & $z$-stat & & Coeff. & $z$-stat & & Coeff. & $z$-stat & & Coeff. & $z$-stat & \\
\hline \multicolumn{13}{|l|}{ Borrower characteristics: } \\
\hline $\log \left(\right.$ Assets $\left._{\mathrm{t}-1}\right)$ & 0.05 & 1.65 & * & -0.09 & 3.36 & **** & -0.02 & 1.09 & & -0.03 & 1.76 & * \\
\hline $\mathrm{ROA}_{\mathrm{t}-1}$ (ind. adj.) & -0.50 & 1.24 & & 0.87 & 2.23 & ** & -0.19 & 2.04 & ** & -0.01 & 0.30 & \\
\hline Leverage $_{t-1}$ (ind. adj.) & 0.50 & 3.83 & *** & -- & & & -0.08 & 1.71 & * & -- & & \\
\hline Coverage $_{\mathrm{t}-1}$ (ind. adj.) & 0.01 & 1.76 & * & -- & & & 0.00 & 1.48 & & -- & & \\
\hline Z-score $_{\mathrm{t}-1}$ (ind. adj.) & -- & -- & & -0.01 & 3.82 & **** & -- & & & -0.00 & 0.35 & \\
\hline Compustat (dummy) & -0.45 & 3.34 & *** & 0.21 & 0.98 & & 0.30 & 1.75 & * & 0.29 & 1.61 & \\
\hline \multicolumn{13}{|l|}{ Loan characteristics: } \\
\hline Log (Loan maturity) & -3.35 & 2.60 & **** & -3.84 & 3.11 & **** & 5.15 & 4.53 & **** & 4.54 & 2.88 & **** \\
\hline $\log ($ Loan size $)$ & -0.08 & 1.87 & * & 0.00 & 0.03 & & 0.09 & 4.29 & **** & 0.11 & 3.75 & **** \\
\hline All-in-drawn spread (bps) & -0.00 & 0.64 & & -0.00 & 0.08 & & 0.00 & 1.03 & & 0.00 & 1.31 & \\
\hline Perf. pricing (dummy) & -0.07 & 1.14 & & -0.15 & 2.48 & ** & 0.01 & 0.13 & & 0.02 & 0.31 & \\
\hline LBO loan (dummy) & 0.04 & 0.40 & & -0.07 & 0.49 & & 0.17 & 3.16 & $* * *$ & 0.21 & 2.77 & "**** \\
\hline M\&A loan (dummy) & 0.10 & 0.77 & & 0.12 & 0.83 & & 0.05 & 0.78 & & 0.06 & 0.69 & \\
\hline Debt repayment (dummy) & 0.01 & 0.15 & & 0.02 & 0.17 & & 0.09 & 1.09 & & 0.20 & 1.89 & * \\
\hline \multicolumn{13}{|l|}{ Fixed effects: } \\
\hline Borrower: Industry/Rating & $\mathrm{Y} / \mathrm{Y}$ & & & $\mathrm{Y} / \mathrm{Y}$ & & & $\mathrm{Y} / \mathrm{Y}$ & & & $\mathrm{Y} / \mathrm{Y}$ & & \\
\hline Loan: Year/Lead & $\mathrm{Y} / \mathrm{Y}$ & & & $\mathrm{Y} / \mathrm{Y}$ & & & $\mathrm{Y} / \mathrm{Y}$ & & & $\mathrm{Y} / \mathrm{Y}$ & & \\
\hline Pseudo $R$-squared & 0.29 & & & 0.35 & & & 0.26 & & & 0.30 & & \\
\hline Observations & 361 & & & 265 & & & 738 & & & 539 & & \\
\hline
\end{tabular}


Table 3

Does securitization predict worse future performance? (H1): Secondary market loan prices

This table compares the change in secondary market loan prices for securitized loans and unsecuritized loans. The unit of observation for the analysis is a loan. For each loan we use prices corresponding to the relevant facility (i.e., we only use one facility per loan). The dependent variable is the percentage change in the average monthly mid-quote price (the average between the bid and ask price) in a given period after the loan origination. Facility level controls include facility size as a percentage of the total deal size, and a dummy equal to 1 when the facility starts after the loan origination date (the coefficient on the latter is not reported because it only affects one specification.) The at-origination sample includes loans originated between 1997 and May 2007. The portfolio sample includes loans originated between January 2005 and July 2007. Securitized in 2005-2007 is essentially an interaction term reflecting the marginal effect for loans securitized between 2005 and 2007, which we include for comparison across the two samples. The $p$-value corresponds to the statistical test of the null hypothesis that Securitized + Securitized in 2005-2007=0. Other variable definitions are the same as in Table 1. All specifications include fixed effects for the year of loan origination, the borrower's industry (2-digit SIC code) and rating at origination, and the identity of the loan lead arranger. We use the most granular rating information; e.g., we include separate dummies for BB+, BB, and BB-. Rating fixed effects are relative to the omitted category unrated. Standard errors are clustered by loan lead arranger. Significance at the $1 \%, 5 \%$, and $10 \%$ levels is indicated by ${ }^{* * *},{ }^{* *}$, and ${ }^{*}$, respectively.

\begin{tabular}{|c|c|c|c|c|c|c|c|c|c|c|c|c|}
\hline & \multicolumn{6}{|c|}{ At-origination sample } & \multicolumn{6}{|c|}{ Portfolio sample } \\
\hline & \multicolumn{3}{|c|}{$\begin{array}{c}0-12 \text { months } \\
\text { post-event }\end{array}$} & \multicolumn{3}{|c|}{$\begin{array}{c}\text { 13-24 months } \\
\text { post-event }\end{array}$} & \multicolumn{3}{|c|}{$\begin{array}{l}0-12 \text { months } \\
\text { post-event }\end{array}$} & \multicolumn{3}{|c|}{$\begin{array}{c}\text { 13-24 months } \\
\text { post-event }\end{array}$} \\
\hline & Coeff. & $t$-stat & & Coeff. & $t$-stat & & Coeff. & $t$-stat & & Coeff. & $t$-stat & \\
\hline Securitized (dummy) & -0.011 & 1.34 & & 0.048 & 2.35 & *** & -- & & & -- & & \\
\hline Securitized in 2005-2007 & -0.007 & 0.90 & & -0.027 & 0.20 & & 0.003 & 1.39 & & -0.020 & 2.45 & $* * *$ \\
\hline \multicolumn{13}{|l|}{ Borrower characteristics: } \\
\hline Realized price volatility & -2.262 & 4.02 & *** & -1.229 & 4.86 & $* * *$ & -2.835 & 10.5 & **** & -1.553 & 3.46 & $* * *$ \\
\hline \multicolumn{13}{|l|}{ Loan characteristics: } \\
\hline Log(Loan maturity) & 0.004 & 0.31 & & 0.022 & 0.71 & & -0.077 & 0.91 & & 0.140 & 0.60 & \\
\hline $\log ($ Loan size $)$ & 0.009 & 1.36 & & -0.007 & 0.54 & & 0.001 & 1.57 & & -0.004 & 0.63 & \\
\hline All-in-drawn spread & 0.000 & 0.91 & & -0.000 & 0.88 & & 0.000 & 0.69 & & 0.000 & 0.04 & \\
\hline Perf. pricing (dummy) & 0.000 & 0.05 & & -0.025 & 1.91 & * & -0.003 & 0.84 & & -0.007 & 0.95 & \\
\hline LBO loan (dummy) & -0.001 & 0.09 & & 0.044 & 1.78 & * & 0.002 & 0.31 & & 0.003 & 0.16 & \\
\hline M\&A loan (dummy) & 0.004 & 0.27 & & 0.036 & 1.18 & & -0.000 & 0.07 & & 0.012 & 0.69 & \\
\hline Debt repayment (dummy) & 0.001 & 0.06 & & 0.074 & 2.45 & **** & 0.001 & 0.24 & & -0.030 & 2.10 & *** \\
\hline Facility size (\% of deal) & 0.000 & 1.07 & & -0.001 & 2.18 & $* *$ & 0.000 & 0.98 & & -0.001 & 1.40 & \\
\hline \multicolumn{13}{|l|}{ Fixed effects: } \\
\hline Borrower: Industry/Rating & $\mathrm{Y} / \mathrm{Y}$ & & & $\mathrm{Y} / \mathrm{Y}$ & & & $\mathrm{Y} / \mathrm{Y}$ & & & $\mathrm{Y} / \mathrm{Y}$ & & \\
\hline Loan: Year/Lead & $\mathrm{Y} / \mathrm{Y}$ & & & $\mathrm{Y} / \mathrm{Y}$ & & & $\mathrm{Y} / \mathrm{Y}$ & & & $\mathrm{Y} / \mathrm{Y}$ & & \\
\hline$F$-test ( $p$-value) & 0.12 & & & 0.86 & & & -- & & & -- & & \\
\hline Adjusted $R$-squared & 0.81 & & & 0.81 & & & 0.89 & & & 0.65 & & \\
\hline Observations & 142 & & & 129 & & & 263 & & & 275 & & \\
\hline
\end{tabular}




\section{Table 4}

Does securitization predict worse future performance? (H1): Loan rating changes

This table compares downgrades and upgrades in loan ratings for securitized and unsecuritized loans. The unit of observation for the analysis is a loan. The dependent variable in the regressions is a dummy that indicates whether a loan was downgraded or upgraded in a given period after loan origination. Letter ratings have been converted into a numerical scale $(1=\mathrm{AAA}, 2=\mathrm{AA}+, 3=\mathrm{AA}$, etc.) where credit watch negative or positive counts at + or -0.5 , respectively. Borrowers are considered to be "downgraded" or "upgraded" when the numerical rating changes. Ratings data comes from Reuters Gold Sheets (compiled from S\&P and Moody's) and covers the period from May 2001 through April 2010. The at-origination sample includes loans originated between 1997 and May 2007. The portfolio sample includes loans originated between January 2005 and July 2007. The 2005-2007 dummy equals one for loans originated between 2005 and 2007, zero otherwise. Securitized in 2005-2007 is essentially an interaction term reflecting the marginal effect for loans securitized between 2005 and 2007. The $p$-value corresponds to the statistical test of the null hypothesis that Securitized + Securitized in 2005-2007=0. Other variable definitions are the same as in Table 1. All specifications include fixed effects for the year of loan origination, the borrower's industry (2-digit SIC code) and rating at origination, and the identity of the loan lead arranger. We use the most granular rating information; e.g., we include separate dummies for BB+, BB, and BB-. Rating fixed effects are relative to the omitted category unrated. All specifications are estimated using a linear model to maintain consistency across samples; specifications for the at-origination sample (in this table and in Table 9) require interaction effects which present issues in nonlinear models. Results for the portfolio sample regressions, which do not feature an interaction effect, are qualitatively unchanged using a probit specification. Standard errors are clustered by loan lead arranger. Significance at the $1 \%, 5 \%$, and $10 \%$ levels is indicated by ${ }^{* * * * * *},{ }^{*}$, and ${ }^{*}$, respectively.

Panel A: Downgrades

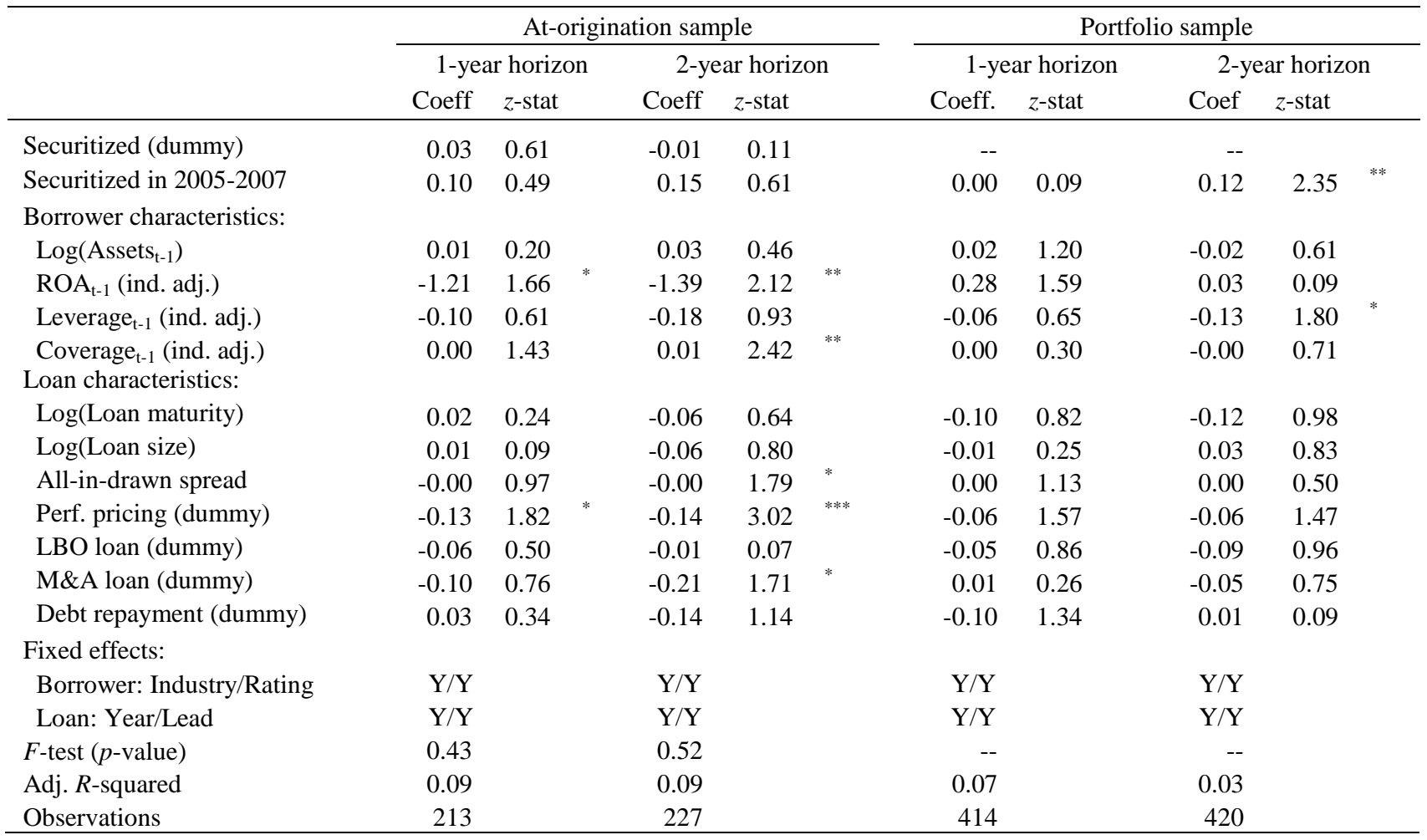


Table 4 - continued

Panel B: Upgrades

\begin{tabular}{|c|c|c|c|c|c|c|c|c|c|c|c|c|}
\hline & \multicolumn{6}{|c|}{ At-origination sample } & \multicolumn{6}{|c|}{ Portfolio sample } \\
\hline & \multicolumn{3}{|c|}{ 1-year horizon } & \multicolumn{3}{|c|}{ 2-year horizon } & \multicolumn{3}{|c|}{ 1-year horizon } & \multicolumn{3}{|c|}{ 2-year horizon } \\
\hline & Coeff & $z$-stat & & Coeff & $z$-stat & & Coeff. & $z$-stat & & Coef & $z$-stat & \\
\hline Securitized (dummy) & 0.08 & 0.73 & & 0.04 & 0.46 & & -- & & & -- & & \\
\hline Securitized in 2005-2007 & -0.14 & 0.77 & & -0.35 & 2.26 & $* *$ & -0.04 & 0.83 & & -0.00 & 0.00 & \\
\hline \multicolumn{13}{|l|}{ Borrower characteristics: } \\
\hline $\log \left(\right.$ Assets $\left._{t-1}\right)$ & -0.07 & 1.39 & & -0.07 & 1.02 & & 0.03 & 1.72 & $*$ & 0.03 & 1.36 & \\
\hline $\mathrm{ROA}_{\mathrm{t}-1}$ (ind. adj.) & 0.15 & 0.29 & & 0.09 & 0.15 & & -0.11 & 0.50 & & -0.55 & 2.18 & ** \\
\hline Leverage $_{\mathrm{t}-1}$ (ind. adj.) & 0.10 & 0.31 & & 0.21 & 0.78 & & -0.01 & 0.11 & & -0.03 & 0.32 & \\
\hline Coverage $_{\mathrm{t}-1}$ (ind. adj.) & -0.00 & 0.21 & & 0.00 & 0.53 & & 0.00 & 0.10 & & 0.00 & 0.78 & \\
\hline \multicolumn{13}{|l|}{ Loan characteristics: } \\
\hline Log(Loan maturity) & 0.00 & 0.04 & & 0.06 & 0.47 & & -0.03 & 0.21 & & -0.07 & 0.42 & \\
\hline $\log ($ Loan size $)$ & 0.10 & 2.00 & $* *$ & 0.10 & 1.57 & & 0.01 & 0.55 & & 0.02 & 0.78 & \\
\hline All-in-drawn spread & -0.00 & 0.01 & & 0.00 & 0.47 & & -0.00 & 0.52 & & 0.00 & 0.13 & \\
\hline Perf. pricing (dummy) & 0.09 & 2.16 & $* *$ & 0.12 & 2.38 & $* *$ & 0.04 & 0.96 & & 0.04 & 0.77 & \\
\hline LBO loan (dummy) & 0.04 & 0.28 & & -0.07 & 0.48 & & 0.06 & 0.94 & & 0.05 & 1.65 & $*$ \\
\hline M\&A loan (dummy) & -0.05 & 0.53 & & -0.18 & 1.25 & & -0.01 & 0.12 & & -0.00 & 0.03 & \\
\hline Debt repayment (dummy) & 0.08 & 1.08 & & -0.10 & 0.79 & & -0.05 & 0.61 & & 0.00 & 0.07 & \\
\hline \multicolumn{13}{|l|}{ Fixed effects: } \\
\hline Borrower: Industry/Rating & $\mathrm{Y} / \mathrm{Y}$ & & & $\mathrm{Y} / \mathrm{Y}$ & & & $\mathrm{Y} / \mathrm{Y}$ & & & $\mathrm{Y} / \mathrm{Y}$ & & \\
\hline Loan: Year/Lead & $\mathrm{Y} / \mathrm{Y}$ & & & $\mathrm{Y} / \mathrm{Y}$ & & & $\mathrm{Y} / \mathrm{Y}$ & & & $\mathrm{Y} / \mathrm{Y}$ & & \\
\hline$F$-test $(p$-value $)$ & 0.62 & & & 0.01 & & & -- & & & -- & & \\
\hline Adj. $R$-squared & 0.15 & & & 0.02 & & & 0.02 & & & 0.10 & & \\
\hline Observations & 213 & & & 227 & & & 414 & & & 420 & & \\
\hline
\end{tabular}




\section{Table 5}

Does securitization predict worse future performance? (H1): CDS spread

This table compares the change in spreads on senior debt credit default swaps (CDS) for securitized loan borrowers with that of unsecuritized borrowers. The unit of observation for the analysis is a loan. The dependent variable is the percentage change in a borrower's CDS spread in a given period after the loan origination. CDS data comes from Markit and corresponds to 5-year contracts. CDS quotes are available for the period 2003 through June 2009. The at-origination sample includes loans originated between 1997 and May 2007. The portfolio sample includes loans originated between January 2005 and July 2007. Securitized in 2005-2007 is essentially an interaction term reflecting the marginal effect for loans securitized between 2005 and 2007. The $p$-value corresponds to the statistical test of the null hypothesis that Securitized + Securitized in 2005-2007=0. Other variable definitions are the same as in Table 1.

Specifications include fixed effects for the year of loan origination, the borrower's industry (2-digit SIC code) and rating at origination, and the identity of the loan lead arranger. We use the most granular rating information; e.g., we include separate dummies for BB+, BB, and BB-. Rating fixed effects are relative to the omitted category unrated. In the at-origination sample, we omit some of the borrowerlevel fixed effects due to the small sample size. Standard errors are clustered by loan lead arranger. Significance at the 1\%, 5\%, and $10 \%$ levels is indicated by ${ }^{* * * * * *}$, and ${ }^{*}$, respectively.

\begin{tabular}{|c|c|c|c|c|c|c|c|c|c|c|c|}
\hline & \multicolumn{6}{|c|}{ At-origination sample } & \multicolumn{5}{|c|}{ Portfolio sample } \\
\hline & \multicolumn{3}{|c|}{$\begin{array}{l}0-12 \text { months } \\
\text { post-event }\end{array}$} & \multicolumn{3}{|c|}{$\begin{array}{c}\text { 13-24 months } \\
\text { post-event }\end{array}$} & \multicolumn{2}{|c|}{$\begin{array}{c}\text { 0-12 months } \\
\text { post-event }\end{array}$} & \multicolumn{3}{|c|}{$\begin{array}{c}\text { 13-24 months } \\
\text { post-event }\end{array}$} \\
\hline & Coeff. & $t$-stat & & Coeff. & $t$-stat & & Coeff. & $t$-stat & Coeff. & $t$-stat & \\
\hline Securitized (dummy) & -0.91 & 1.04 & & 0.42 & 0.89 & & -- & & -- & & \\
\hline Securitized in $2005-2007$ & -0.01 & 0.00 & & -2.21 & 2.28 & $* *$ & 0.34 & 1.36 & 0.24 & 0.78 & \\
\hline \multicolumn{12}{|l|}{ Borrower characteristics: } \\
\hline Realized CDS vol. & 0.02 & 1.25 & & 0.00 & 0.94 & & 0.00 & 0.67 & 0.01 & 4.09 & **** \\
\hline \multicolumn{12}{|l|}{ Loan characteristics: } \\
\hline $\log ($ Loan maturity) & -1.62 & 2.87 & $* * *$ & -0.16 & 0.75 & & -0.05 & 0.08 & -0.64 & 1.27 & \\
\hline $\log ($ Loan size $)$ & -0.40 & 0.25 & & -0.32 & 3.15 & **** & 0.06 & 0.73 & -0.08 & 0.62 & \\
\hline All-in-drawn spread & -0.01 & 1.75 & $*$ & -0.00 & 3.12 & **** & -0.00 & 0.23 & -0.00 & 0.23 & \\
\hline Performance pricing & -1.24 & 0.65 & & 0.14 & 0.75 & & 0.04 & 0.30 & 0.50 & 2.55 & ** \\
\hline LBO loan (dummy) & 0.74 & 0.49 & & 0.72 & 1.25 & & 0.21 & 0.99 & 0.42 & 0.57 & \\
\hline M\&A loan (dummy) & 4.30 & 3.72 & **** & 3.97 & 10.7 & **** & 0.27 & 1.06 & -0.04 & 0.05 & \\
\hline Debt repayment (dummy) & -2.41 & 1.97 & *** & 1.55 & 2.13 & *** & -0.50 & 1.34 & 0.41 & 0.98 & \\
\hline \multicolumn{12}{|l|}{ Fixed effects: } \\
\hline Borrower: Industry/Rating & $\mathrm{N} / \mathrm{N}$ & & & N/Y & & & $\mathrm{Y} / \mathrm{Y}$ & & $\mathrm{Y} / \mathrm{Y}$ & & \\
\hline Loan: Year/Lead & $\mathrm{Y} / \mathrm{Y}$ & & & $\mathrm{Y} / \mathrm{Y}$ & & & $\mathrm{Y} / \mathrm{Y}$ & & $\mathrm{Y} / \mathrm{Y}$ & & \\
\hline$F$-test ( $p$-value) & 0.71 & & & 0.02 & & & -- & & -- & & \\
\hline Adjusted $R$-squared & 0.54 & & & 0.73 & & & 0.62 & & 0.59 & & \\
\hline Observations & 24 & & & 44 & & & 157 & & 170 & & \\
\hline
\end{tabular}




\section{Table 6}

Does securitization predict worse future performance? (H1): Implied probability of default

This table compares post-origination changes in implied probability of default $(\Pi)$ for borrowers whose loans were securitized and borrowers whose loans were not securitized. Implied default probabilities are calculated using the reduced form Merton (1974)-style approach described in Bharath and Shumway (2008). The unit of observation for the analysis is a loan. The dependent variable is the change in the borrower's implied 1-year default probability over the window. The $t-1$ implied default probability $\left(\Pi_{\mathrm{t}-1}\right)$ is measured as of month-end in the month before loan origination. The at-origination sample includes loans originated between 1997 and May 2007. The portfolio sample includes loans originated between January 2005 and July 2007. Securitized in 2005-2007 is essentially an interaction term reflecting the marginal effect for loans securitized between 2005 and 2007 . The $p$-value corresponds to the statistical test of the null hypothesis that Securitized + Securitized in 2005-2007=0. Other variable definitions are the same as in Table 1. All specifications include fixed effects for the year of loan origination, the borrower's industry (2-digit SIC code) and rating at origination, and the identity of the loan lead arranger. We use the most granular rating information; e.g., we include separate dummies for BB+, BB, and BB-. Rating fixed effects are relative to the omitted category unrated. Standard errors are clustered by loan lead arranger in all specifications.

Significance at the 1,5 , and 10 percent levels is indicated by ${ }^{* * *},{ }^{* * *}$, and ${ }^{*}$, respectively.

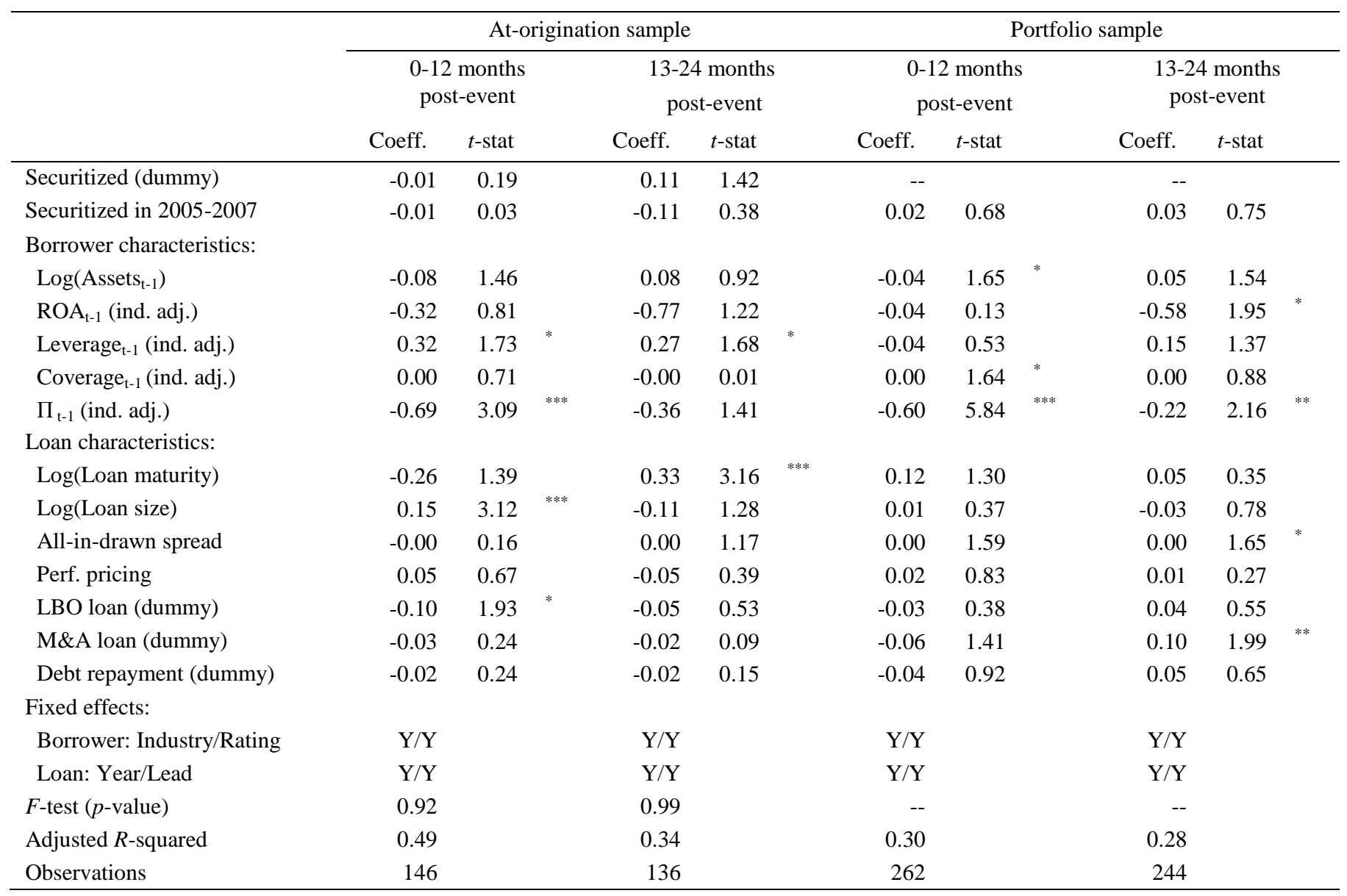




\section{Table 7}

Loan selection under CLO demand pressure (quasi-experiment)

This table seeks to address a potential selection bias. We replicated results in Tables 3-6 using three alternative proxies for CLO demand for loans. The basic idea is to look at the marginal quality of loans securitized in periods when the CLO demand for loans is generally high. In addition to controls used in the analysis in Tables 3 to 6 we include a fund-flow proxy and its interaction with the Securitized dummy. Coefficients on benchmark controls and fund-flow proxies are omitted for compactness of presentation. The table reports coefficients of interest for 44 different regressions (11 specifications x 4 measures of demand). CLO issuance (in billions) is equivalent to CLO fund flow. $\triangle C L O$ pipeline (in billions) is the accumulation of CLOs in the pipeline, i.e., excess demand for loans by CLOs. CLO issuance scaled by total term loan issuance is also likely to reflect imbalances in demand. For robustness, we also report results for net cash flow into institutional accounts scaled by total term loan issuance, which reflects imbalances in institutional demand for loans more broadly. The analysis is done using the at-origination sample which includes loans originated between 1997 and May 2007. Fund flow data is available from 2001 through 2009 . Significance at the $1 \%, 5 \%$, and $10 \%$ levels is indicated by ${ }^{* * *}$, ${ }^{* *}$, and ${ }^{*}$, respectively.

\begin{tabular}{|c|c|c|c|c|c|c|c|c|c|c|c|c|c|}
\hline \multirow[b]{3}{*}{ Table } & \multirow[b]{3}{*}{ Dependent variable } & \multirow[b]{3}{*}{ Explanatory variable } & \multicolumn{9}{|c|}{ CLO demand proxy: } & \multirow{2}{*}{\multicolumn{2}{|c|}{$\begin{array}{l}\text { Net cash flows into } \\
\text { inst. investors/ } \\
\text { Term loan issuance }\end{array}$}} \\
\hline & & & \multicolumn{3}{|c|}{ CLO issuance } & \multicolumn{3}{|c|}{$\Delta$ CLO pipeline } & \multicolumn{3}{|c|}{$\begin{array}{c}\text { CLO issuance/ } \\
\text { Term loan issuance }\end{array}$} & & \\
\hline & & & Coeff. & Stat. & & Coeff. & Stat. & & Coeff. & Stat. & & Coeff. & Stat. \\
\hline \multirow[t]{2}{*}{ Tbl. 3} & $\Delta$ Loan price (1-12 month) & Securitized & -0.011 & 1.48 & & -0.008 & 2.11 & & -0.011 & 0.65 & & -0.003 & 0.39 \\
\hline & & Securitized $*$ CLO demand & 0.000 & 0.51 & & 0.000 & 0.14 & & 0.036 & 0.24 & & -0.050 & 0.74 \\
\hline \multirow[t]{2}{*}{ Tbl. 3} & $\Delta$ Loan price (13-24 month) & Securitized & 0.107 & 1.01 & & 0.011 & 0.41 & & 0.107 & 0.93 & & 0.063 & 0.95 \\
\hline & & Securitized*CLO demand & -0.014 & 1.23 & & -0.039 & 1.23 & & -0.684 & 0.56 & & 0.166 & 0.30 \\
\hline \multirow[t]{2}{*}{ Tbl. 4.a } & Downgrade (1-year) & Securitized & -0.152 & 1.98 & $* *$ & -0.024 & 0.38 & & 0.031 & 0.15 & & 0.039 & 0.49 \\
\hline & & Securitized*CLO demand & 0.021 & 1.51 & & -0.009 & 0.16 & & -0.339 & 0.15 & & -0.211 & 0.15 \\
\hline \multirow[t]{2}{*}{ Tbl. 4.a } & Downgrade (2-year) & Securitized & -0.287 & 1.84 & $*$ & -0.076 & 0.63 & & -0.033 & 0.13 & & -0.059 & 0.36 \\
\hline & & Securitized*CLO demand & 0.032 & 1.98 & $* *$ & -0.052 & 1.03 & & -0.544 & 0.26 & & -0.420 & 0.22 \\
\hline \multirow[t]{2}{*}{ Tbl. 4.b } & Upgrade (1-year) & Securitized & 0.092 & 0.66 & & 0.032 & 0.35 & & 0.034 & 0.27 & & 0.071 & 0.63 \\
\hline & & Securitized*CLO demand & -0.008 & 0.84 & & 0.021 & 0.99 & & 0.084 & 0.09 & & -1.273 & 1.39 \\
\hline \multirow[t]{2}{*}{ Tbl. 4.b } & Upgrade (2-year) & Securitized & 0.081 & 0.47 & & -0.075 & 0.74 & & -0.026 & 0.22 & & -0.066 & 0.53 \\
\hline & & Securitized*CLO demand & -0.021 & 1.35 & & 0.036 & 1.25 & & -0.299 & 0.30 & & 0.425 & 0.35 \\
\hline \multirow[t]{2}{*}{ Tbl. 5} & $\Delta \mathrm{CDS}$ (1-12 month) & Securitized & 0.065 & 0.09 & & -1.063 & 0.91 & & 0.494 & 0.35 & & -1.285 & 1.12 \\
\hline & & Securitized*CLO demand & -0.128 & 0.79 & & 0.119 & 0.26 & & -22.71 & 0.81 & & -0.929 & 0.16 \\
\hline \multirow[t]{2}{*}{ Tbl. 5} & $\Delta \mathrm{CDS}$ (13-24 month) & Securitized & 0.776 & 0.90 & & 0.382 & 1.10 & & 2.105 & 0.94 & & -0.391 & 0.75 \\
\hline & & Securitized*CLO demand & -0.125 & 1.29 & & -0.431 & 3.04 & *** & -20.53 & 0.95 & & 4.238 & 0.86 \\
\hline \multirow[t]{2}{*}{ Tbl. 6} & $\Delta \Pi(0-12$ month $)$ & Securitized & -0.127 & 1.80 & $*$ & 0.005 & 0.11 & & -0.156 & 0.89 & & 0.045 & 0.87 \\
\hline & & Securitized*CLO demand & 0.030 & 2.92 & *** & 0.009 & 0.39 & & 1.944 & 1.06 & & 0.216 & 0.49 \\
\hline \multirow[t]{2}{*}{ Tbl. 6} & $\Delta \Pi$ (12-24 month) & Securitized & -0.054 & 0.32 & & -0.013 & 0.13 & & -0.323 & 1.77 & $*$ & -0.095 & 0.81 \\
\hline & & Securitized*CLO demand & 0.002 & 0.09 & & 0.070 & 1.21 & & 3.002 & 2.22 & $* *$ & 0.242 & 0.15 \\
\hline
\end{tabular}




\section{Table 8}

Does securitization by the originator predict worse future performance? (H2): Secondary market loan prices

This table compares the change in secondary market loan prices following loan origination for borrowers whose loans were securitized by their lead arranger versus other securitized loans in the same CLO portfolio. The sample only includes securitized loans. The unit of observation for the analysis is CLO x loan. For each loan we use prices corresponding to the relevant facility (i.e., we only use one facility per loan). The dependent variable is the percentage change in the average monthly loan price in a given period after loan origination. We use mid-quotes (i.e., the average between bid and ask spread). Facility level controls include facility size as a percentage of the total deal size, and a dummy equal to 1when facility starts after the loan origination date (coefficient on the latter is not reported because it only affects one specification.) The focus is on the Same bank dummy equal to 1 when a loan appears in a CLO underwritten by its lead arranger and 0 otherwise. Same bank 2005-2007 is essentially an interaction term reflecting the marginal effect for loans originated between 2005 and 2007. The $p$-value corresponds to the statistical test of the null hypothesis that Same bank + Same bank 2005-2007=0. All specifications include fixed effects for the year of loan origination, the borrower's industry (2-digit SIC code) and rating at origination, and the identity of the loan lead arranger. We use the most granular rating information; e.g., we include separate dummies for $\mathrm{BB}+, \mathrm{BB}$, and BB-. Rating fixed effects are relative to the omitted category unrated. Standard errors are clustered by loan. Significance at the $1 \%, 5 \%$, and $10 \%$ levels is indicated by ${ }^{* * *},{ }^{* *}$, and ${ }^{*}$, respectively.

\begin{tabular}{|c|c|c|c|c|c|c|}
\hline & \multicolumn{6}{|c|}{ At-origination sample } \\
\hline & \multicolumn{3}{|c|}{$\begin{array}{c}\text { 0-12 months } \\
\text { post-event }\end{array}$} & \multicolumn{3}{|c|}{$\begin{array}{c}\text { 13-24 months } \\
\text { post-event }\end{array}$} \\
\hline & Coeff. & $t$-stat & & Coeff. & $t$-stat & \\
\hline Same bank (dummy) & 0.001 & 1.99 & $* *$ & 0.009 & 2.24 & \\
\hline Same bank, 2005-2007 & 0.001 & 1.04 & & -0.014 & 2.11 & \\
\hline \multicolumn{7}{|l|}{ Borrower characteristics: } \\
\hline Realized price volatility & -1.855 & 36.5 & **** & 0.487 & 0.86 & \\
\hline \multicolumn{7}{|l|}{ Loan characteristics: } \\
\hline Log(Loan maturity) & 0.387 & 2.45 & ** & 0.903 & 1.93 & * \\
\hline $\log ($ Loan size $)$ & -0.011 & 2.10 & ** & 0.018 & 0.88 & \\
\hline All-in-drawn spread & 0.001 & 4.50 & $* * *$ & 0.001 & 1.66 & $*$ \\
\hline Performance pricing & 0.004 & 0.86 & & 0.049 & 2.05 & $* *$ \\
\hline LBO loan (dummy) & -0.030 & 3.32 & *** & -0.106 & 2.74 & $* * *$ \\
\hline M\&A loan (dummy) & -0.064 & 7.12 & $* * *$ & -0.028 & 0.60 & \\
\hline Debt repayment (dummy) & -0.012 & 0.92 & & 0.179 & 4.50 & *** \\
\hline Facility size (\% of deal) & -0.000 & 1.17 & & -0.005 & 5.85 & $* * *$ \\
\hline \multicolumn{7}{|l|}{ Fixed effects: } \\
\hline Borrower: Industry/Rating & $\mathrm{Y} / \mathrm{Y}$ & & & $\mathrm{Y} / \mathrm{Y}$ & & \\
\hline Loan: Year/Lead & $\mathrm{Y} / \mathrm{Y}$ & & & $\mathrm{Y} / \mathrm{Y}$ & & \\
\hline$F$-test ( $p$-value) & 0.14 & & & 0.18 & & \\
\hline Adjusted $R$-squared & 0.99 & & & 0.99 & & \\
\hline Observations & 877 & & & 791 & & \\
\hline
\end{tabular}




\section{Table 9}

Does securitization by the originator predict worse future performance? (H2): Loan rating changes

This table compares the post-origination downgrade and upgrade frequency loans that sold to a CLO underwritten by their lead arranger with other loans securitized in the same portfolio. The sample only includes securitized loans. The unit of observation for the analysis is CLO x loan. The dependent variable in the regressions is a dummy that indicates whether a loan was downgraded or upgraded in a given period after the loan origination date. Letter ratings have been converted into a numerical scale $(1=\mathrm{AAA}, 2=\mathrm{AA}+, 3=\mathrm{AA}$, etc. $)$ where credit watch negative or positive counts at + or -0.5 , respectively. Borrowers are considered to be "downgraded" or "upgraded" when the numerical rating changes. The focus is on the Same bank dummy equal to 1 when a loan appears in a CLO underwritten by its lead arranger and 0 otherwise. Same bank 2005-2007 is essentially an interaction term reflecting the marginal effect for loans originated between 2005 and 2007. The $p$-value corresponds to the statistical test of the null hypothesis that Same bank + Same bank 2005-2007=0. All specifications are estimated using a linear model. Ratings data comes from Reuters Gold Sheets (compiled from S\&P and Moody's) and covers the period from May 2001 through April 2010. Variable definitions are the same as in Table 1. All specifications include fixed effects for the year of loan origination, the borrower's industry (2-digit SIC code) and rating at origination, and the identity of the loan lead arranger. We use the most granular rating information; e.g., we include separate dummies for BB+, BB, and BB-. Rating fixed effects are relative to the omitted category unrated. Standard errors are clustered by loan. Significance at the $1 \%, 5 \%$, and $10 \%$ levels is indicated by ${ }^{* * *},{ }^{* *}$, and ${ }^{*}$, respectively.

Panel A: Downgrades

\begin{tabular}{|c|c|c|c|c|c|c|}
\hline & \multicolumn{6}{|c|}{ At-origination sample } \\
\hline & \multicolumn{3}{|c|}{ 1-year horizon } & \multicolumn{3}{|c|}{ 2-year horizon } \\
\hline & Coeff. & $z$-stat & & Coeff. & $z$-stat & \\
\hline Same bank (dummy) & 0.06 & 1.45 & & 0.004 & 0.10 & \\
\hline Same bank, 2005-2007 & -0.01 & 0.14 & & 0.08 & 0.83 & \\
\hline \multicolumn{7}{|l|}{ Borrower characteristics: } \\
\hline $\log \left(\right.$ Assets $\left._{t-1}\right)$ & 0.06 & 0.96 & & 0.17 & 2.34 & ** \\
\hline $\mathrm{ROA}_{\mathrm{t}-1}$ (ind. adj.) & -1.06 & 1.85 & & -0.77 & 1.29 & \\
\hline Leverage $_{\mathrm{t}-1}$ (ind. adj.) & -0.02 & 0.12 & & -0.04 & 0.26 & \\
\hline Coverage $_{\mathrm{t}-1}$ (ind. adj.) & 0.01 & 1.77 & * & 0.01 & 2.47 & *** \\
\hline \multicolumn{7}{|l|}{ Loan characteristics: } \\
\hline Log(Loan maturity) & 0.13 & 1.01 & & -0.11 & 1.01 & \\
\hline $\log ($ Loan size $)$ & -0.06 & 0.82 & & -0.14 & 1.84 & * \\
\hline All-in-drawn spread & 0.00 & 1.26 & & -0.00 & 2.01 & *** \\
\hline Perf. pricing (dummy) & -0.17 & 1.58 & & -0.29 & 3.34 & **** \\
\hline LBO loan (dummy) & 0.01 & 0.09 & & 0.12 & 0.70 & \\
\hline M\&A loan (dummy) & 0.01 & 0.05 & & -0.00 & 0.02 & \\
\hline Debt repayment (dummy) & 0.22 & 1.82 & 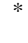 & 0.36 & 1.91 & * \\
\hline \multicolumn{7}{|l|}{ Fixed effects: } \\
\hline Borrower: Industrv/Rating & $\mathrm{Y} / \mathrm{Y}$ & & & $\mathrm{Y} / \mathrm{Y}$ & & \\
\hline Loan: Year/Lead & $\mathrm{Y} / \mathrm{Y}$ & & & $\mathrm{Y} / \mathrm{Y}$ & & \\
\hline$F$-test ( $p$-value) & 0.47 & & & 0.33 & & \\
\hline Adjusted $R$-squared & 0.49 & & & 0.59 & & \\
\hline Observations & 1,228 & & & 1,334 & & \\
\hline
\end{tabular}


Table 9 - continued

Panel B: Upgrades

\begin{tabular}{|c|c|c|c|c|c|c|}
\hline & \multicolumn{6}{|c|}{ At-origination sample } \\
\hline & \multicolumn{3}{|c|}{ 1-year horizon } & \multicolumn{3}{|c|}{ 2-year horizon } \\
\hline & Coeff. & $z$-stat & & Coeff. & $z$-stat & \\
\hline Same bank (dummy) & -0.04 & 1.03 & & -0.04 & 0.99 & \\
\hline Same bank, 2005-2007 & -0.001 & 0.01 & & 0.03 & 0.36 & \\
\hline \multicolumn{7}{|l|}{ Borrower characteristics: } \\
\hline $\log \left(\right.$ Assets $\left._{\mathrm{t}-1}\right)$ & -0.20 & 2.96 & ${ }^{* * * *}$ & -0.13 & 1.58 & \\
\hline $\mathrm{ROA}_{\mathrm{t}-1}$ (ind. adj.) & 0.24 & 0.56 & & 0.19 & 0.40 & \\
\hline Leverage $_{\mathrm{t}-1}$ (ind. adj.) & -0.32 & 2.21 & ** & -0.06 & 0.33 & \\
\hline Coverage $_{t-1}$ (ind. adj.) & -0.01 & 2.51 & ** & -0.00 & 0.61 & \\
\hline \multicolumn{7}{|l|}{ Loan characteristics: } \\
\hline $\log ($ Loan maturity $)$ & -0.03 & 0.27 & & 0.08 & 0.62 & \\
\hline $\log ($ Loan size $)$ & 0.06 & 0.84 & & 0.03 & 0.33 & \\
\hline All-in-drawn spread & -0.00 & 0.77 & & 0.00 & 0.50 & \\
\hline Perf. pricing (dummy) & 0.15 & 1.84 & * & 0.30 & 2.62 & *** \\
\hline LBO loan (dummy) & -0.15 & 0.93 & & -0.26 & 1.53 & 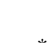 \\
\hline M\&A loan (dummy) & -0.44 & 3.26 & **** & -0.35 & 1.95 & \\
\hline Debt repayment (dummy) & 0.18 & 1.04 & & 0.16 & 0.85 & \\
\hline \multicolumn{7}{|l|}{ Fixed effects: } \\
\hline Borrower: Industrv/Rating & $\mathrm{Y} / \mathrm{Y}$ & & & $\mathrm{Y} / \mathrm{Y}$ & & \\
\hline Loan: Year/Lead & $\mathrm{Y} / \mathrm{Y}$ & & & $\mathrm{Y} / \mathrm{Y}$ & & \\
\hline$F$-test ( $p$-value) & 0.50 & & & 0.90 & & \\
\hline Adjusted $R$-squared & 0.43 & & & 0.33 & & \\
\hline Observations & 1,228 & & & 1,334 & & \\
\hline
\end{tabular}




\section{Table 10}

Does securitization by the originator predict worse future performance? (H2): Implied probability of default

This table compares post-origination changes in implied probability of default ( $\Pi$ ) for borrowers whose loans were securitized and borrowers whose loans were not securitized. Implied default probabilities are calculated using the reduced form Merton (1974)-style approach described in Bharath and Shumway (2008). The unit of observation for the analysis is a loan. The dependent variable is the change in the borrower's implied 1-year default probability over the window. The $t-1$ implied default probability $\left(\Pi_{\mathrm{t}-1}\right)$ is measured as of month-end in the month before loan origination. The sample only includes securitized loans. The unit of observation for the analysis is CLO x loan. The focus is on the Same bank dummy which is equal to 1 when a loan appears in a CLO underwritten by its lead arranger and 0 otherwise. Same bank 2005-2007 is essentially an interaction term reflecting the marginal effect for loans originated between 2005 and 2007. The $p$-value corresponds to the statistical test of the null hypothesis that Same bank + Same bank 2005-2007=0. Specifications include fixed effects for the year of loan origination, the borrower's industry (2-digit SIC code) and rating at origination, and the identity of the loan lead arranger. We use the most granular rating information; e.g., we include separate dummies for BB+, BB, and BB-. Rating fixed effects are relative to the omitted category unrated. We omit year fixed effects because the number of same bank loans is small (150 observations) and the estimation requires enough loans for a within-portfolio comparison with fixed effects. The results are robust to alternatively excluding other types of fixed effects. Standard errors are clustered by loan. Variable definitions are the same as in Table 1. Significance at the $1 \%, 5 \%$, and $10 \%$ levels is indicated by ${ }^{* * *},{ }^{* *}$, and ${ }^{*}$, respectively.

\begin{tabular}{|c|c|c|c|c|c|c|}
\hline & \multicolumn{6}{|c|}{ At-origination sample } \\
\hline & \multicolumn{3}{|c|}{$\begin{array}{c}\text { 0-12 months } \\
\text { post-event }\end{array}$} & \multicolumn{3}{|c|}{$\begin{array}{c}\text { 13-24 months } \\
\text { post-event }\end{array}$} \\
\hline & Coeff. & $t$-stat & & Coeff. & $t$-stat & \\
\hline Same bank (dummy) & -0.009 & 1.59 & & 0.002 & 0.15 & \\
\hline Same bank 2005-2007 & -0.058 & 1.00 & & 0.002 & 0.05 & \\
\hline \multicolumn{7}{|l|}{ Borrower characteristics: } \\
\hline $\log \left(\right.$ Assets $\left._{t-1}\right)$ & -0.15 & 3.46 & *** & -0.04 & 0.76 & \\
\hline $\mathrm{ROA}_{\mathrm{t}-1}$ (ind. adj.) & -1.55 & 2.62 & **** & 0.50 & 0.31 & \\
\hline Leverage $_{\mathrm{t}-1}$ (ind. adj.) & -0.18 & 1.03 & & 0.92 & 3.70 & **** \\
\hline Coverage $_{\mathrm{t}-1}$ (ind. adj.) & 0.00 & 0.60 & & -0.01 & 2.97 & **** \\
\hline$\Pi_{\mathrm{t}-1}($ ind. adj. $)$ & -1.11 & 6.62 & ${ }^{* * *}$ & 0.60 & 1.02 & \\
\hline \multicolumn{7}{|l|}{ Loan characteristics: } \\
\hline $\log ($ Loan maturity) & -0.34 & 4.82 & $* * *$ & 0.51 & 4.17 & $* * *$ \\
\hline $\log ($ Loan size $)$ & 0.19 & 2.40 & ${ }^{* *}$ & -0.10 & 0.66 & \\
\hline All-in-drawn spread & 0.00 & 3.31 & **** & -0.00 & 0.56 & \\
\hline Perf. pricing (dummy) & -0.09 & 1.14 & & 0.11 & 1.34 & \\
\hline LBO loan (dummy) & 0.03 & 0.24 & & -0.30 & 1.11 & \\
\hline M\&A loan (dummy) & -0.37 & 3.24 & **** & 0.16 & 0.81 & \\
\hline Debt repayment (dummy) & -0.05 & 0.50 & & -0.25 & 1.66 & * \\
\hline \multicolumn{7}{|l|}{ Fixed effects: } \\
\hline Borrower: Industry/Rating & $\mathrm{Y} / \mathrm{Y}$ & & & $\mathrm{Y} / \mathrm{Y}$ & & \\
\hline Loan: Year/Lead & $\mathrm{N} / \mathrm{Y}$ & & & $\mathrm{N} / \mathrm{Y}$ & & \\
\hline$F$-test ( $p$-value) & 0.26 & & & 0.90 & & \\
\hline Adjusted $R$-squared & 0.98 & & & 0.96 & & \\
\hline Observations & 748 & & & 732 & & \\
\hline
\end{tabular}




\section{Table 11}

Robustness check: frequency of covenant violations

This table compares the frequency of covenant violations across groups of loans that correspond to the two hypotheses tested in the paper. The unit of observation for the analysis is a loan. Number of financial covenants is the number of covenants on the loan at origination. Covenant violations were compiled from loan amendments remarks as reported in DealScan. The at-origination sample includes loans originated between 1997 and May 2007. The portfolio sample includes loans originated between January 2005 and July 2007 . Significance at the $1 \%, 5 \%$, and $10 \%$ levels is indicated by ${ }^{* * *},{ }^{* *}$, and ${ }^{*}$, respectively.

Panel A: Does securitization predict worse future performance? (H1)

\begin{tabular}{|c|c|c|c|c|c|c|c|c|c|c|c|c|}
\hline & \multicolumn{7}{|c|}{ At-origination sample } & \multirow{2}{*}{\multicolumn{4}{|c|}{$\begin{array}{c}\text { Portfolio sample } \\
\text { Originated 2005-2007 }\end{array}$}} \\
\hline & & \multirow{2}{*}{\multicolumn{3}{|c|}{$\begin{array}{l}\text { Originated 1997-2004 } \\
\text { Securitized: }\end{array}$}} & & \multicolumn{3}{|c|}{ Originated 2005-2007 } & & & & \\
\hline & & & & & & Secur & & & \multicolumn{4}{|c|}{ Securitized: } \\
\hline & & Yes & No & $t$-stat & & Yes & No & $t$-stat & Yes & No & $t$-stat & \\
\hline Number of loans & & 245 & 151 & \multirow{5}{*}{2.04} & & 57 & 34 & \multirow{5}{*}{1.01} & 1,084 & 2,508 & \multirow{5}{*}{4.50} & \\
\hline \multirow[t]{4}{*}{ Number of financial covenants } & Obs. & 245 & 151 & & & 57 & 34 & & 1,084 & 2,508 & & \\
\hline & Mean & 3.28 & 3.56 & & ** & 2.56 & 2.24 & & 0.77 & 0.57 & & *** \\
\hline & Median & 3.00 & 4.00 & & & 3.00 & 2.00 & & 0.00 & 0.00 & & \\
\hline & SD & 1.52 & 1.08 & & & 1.54 & 1.42 & & 1.29 & 1.18 & & \\
\hline \multirow[t]{4}{*}{ Covenant violation, $0-12 \mathrm{mo}$. } & Obs. & 245 & 151 & \multirow{4}{*}{0.12} & & 57 & 34 & \multirow{4}{*}{1.36} & 1,084 & 2,508 & \multirow{4}{*}{1.32} & \\
\hline & Mean & 0.02 & 0.03 & & & 0.05 & 0.00 & & 0.00 & 0.00 & & \\
\hline & Median & 0.00 & 0.00 & & & 0.00 & 0.00 & & 0.00 & 0.00 & & \\
\hline & SD & 0.15 & 0.16 & & & 0.23 & 0.00 & & 0.00 & 0.04 & & \\
\hline \multirow[t]{4}{*}{ Covenant violation, 13-24 mo. } & Obs. & 245 & 151 & \multirow{4}{*}{0.56} & & 57 & 34 & \multirow{4}{*}{0.77} & 1,084 & 2,508 & \multirow{4}{*}{0.23} & \\
\hline & Mean & 0.04 & 0.05 & & & 0.02 & 0.00 & & 0.00 & 0.00 & & \\
\hline & Median & 0.00 & 0.00 & & & 0.00 & 0.00 & & 0.00 & 0.00 & & \\
\hline & SD & 0.20 & 0.22 & & & 0.13 & 0.00 & & 0.03 & 0.03 & & \\
\hline \multirow[t]{4}{*}{ Covenant violation, after $24 \mathrm{mo}$. } & Obs. & 245 & 151 & \multirow{4}{*}{0.75} & & 57 & 34 & \multirow{4}{*}{--} & 1,084 & 2,508 & \multirow{4}{*}{1.38} & \\
\hline & Mean & 0.03 & 0.02 & & & 0.00 & 0.00 & & 0.00 & 0.00 & & \\
\hline & Median & 0.00 & 0.00 & & & 0.00 & 0.00 & & 0.00 & 0.00 & & \\
\hline & $\mathrm{SD}$ & 0.18 & 0.14 & & & 0.00 & 0.00 & & 0.04 & 0.02 & & \\
\hline \multirow[t]{4}{*}{ Covenant violation ever } & Obs. & 245 & 151 & \multirow{4}{*}{0.27} & & 57 & 34 & \multirow{4}{*}{1.36} & 1,084 & 2,508 & \multirow{4}{*}{0.21} & \\
\hline & Mean & 0.07 & 0.07 & & & 0.05 & 0.00 & & 0.00 & 0.00 & & \\
\hline & Median & 0.00 & 0.00 & & & 0.00 & 0.00 & & 0.00 & 0.00 & & \\
\hline & SD & 0.26 & 0.25 & & & 0.23 & 0.00 & & 0.05 & 0.06 & & \\
\hline
\end{tabular}


Table 11 - continued

Panel B: Does securitization by the originator predict worse future performance? (H2)

\begin{tabular}{|c|c|c|c|c|c|c|c|}
\hline & & \multicolumn{6}{|c|}{ At-origination sample } \\
\hline & & \multirow{2}{*}{\multicolumn{3}{|c|}{ Originated 1997-2004 }} & \multicolumn{3}{|c|}{ Originated 2005-2007 } \\
\hline & & & & \multirow[b]{2}{*}{$t$-stat } & \multicolumn{2}{|c|}{ Same bank: } & \multirow[b]{2}{*}{$t$-stat } \\
\hline & & Yes & No & & Yes & No & \\
\hline Number of loans & & 80 & 165 & & 24 & 33 & \\
\hline \multirow[t]{4}{*}{ Number of financial covenants } & Obs. & 80 & 165 & & 24 & 33 & \\
\hline & Mean & 3.24 & 3.30 & 0.32 & 2.54 & 2.58 & 0.08 \\
\hline & Median & 3.00 & 4.00 & & 2.50 & 3.00 & \\
\hline & SD & 1.22 & 1.64 & & 1.72 & 1.41 & \\
\hline \multirow[t]{4}{*}{ Covenant violation, $0-12 \mathrm{mo}}$. & Obs. & 80 & 165 & & 24 & 33 & \\
\hline & Mean & 0.03 & 0.02 & 0.04 & 0.04 & 0.06 & 0.31 \\
\hline & Median & 0.00 & 0.00 & & 0.00 & 0.00 & \\
\hline & $\mathrm{SD}$ & 0.16 & 0.15 & & 0.20 & 0.24 & \\
\hline \multirow[t]{4}{*}{ Covenant violation, 13-24 mo. } & Obs. & 80 & 165 & & 24 & 33 & \\
\hline & Mean & 0.03 & 0.05 & 0.87 & 0.00 & 0.03 & 0.85 \\
\hline & Median & 0.00 & 0.00 & & 0.00 & 0.00 & \\
\hline & $\mathrm{SD}$ & 0.16 & 0.22 & & 0.00 & 0.17 & \\
\hline \multirow[t]{4}{*}{ Covenant violation, after $24 \mathrm{mo}$. } & Obs. & 80 & 165 & & 24 & 33 & \\
\hline & Mean & 0.03 & 0.04 & 0.47 & 0.00 & 0.00 & -- \\
\hline & Median & 0.00 & 0.00 & & 0.00 & 0.00 & \\
\hline & SD & 0.16 & 0.19 & & 0.00 & 0.00 & \\
\hline \multirow[t]{4}{*}{ Covenant violation ever } & Obs. & 80 & 165 & & 24 & 33 & \\
\hline & Mean & 0.05 & 0.08 & 0.98 & 0.04 & 0.06 & 0.31 \\
\hline & Median & 0.00 & 0.00 & & 0.00 & 0.00 & \\
\hline & $\mathrm{SD}$ & 0.22 & 0.28 & & 0.20 & 0.24 & \\
\hline
\end{tabular}

